\title{
The potential of models and modeling for social-ecological systems research: the reference frame ModSES
}

\author{
Maja Schlüter ${ }^{1}$, Birgit Müller ${ }^{2}$ and $\underline{\text { Karin Frank }}^{2,3,4}$
}

\begin{abstract}
Dynamic models have long been a common tool to support management of ecological and economic systems and played a prominent role in the early days of resilience research. Model applications have largely focused on policy assessment, the development of optimal management strategies, or analysis of system stability. However, modeling can serve many other purposes such as understanding system responses that emerge from complex interactions of system components, supporting participatory processes, and analyzing consequences of human behavioral complexity. The diversity of purposes, types, and applications of models offers great potential for social-ecological systems (SESs) research, but has created much confusion because modeling approaches originate from different disciplines, are based on different assumptions, focus on different levels of analysis, and use different analytical methods. This diversity makes it difficult to identify which approach is most suitable for addressing a specific question. Here, our aims are: (1) to introduce the most common types of dynamic models used in SESs research and related fields, and (2) to align these models with SESs research aims to support the selection and communication of the most suitable approach for a given study. To this end, we organize modeling approaches into a reference scheme called "modelling for social-ecological systems research" (ModSES) along two dimensions: the degree of realism and the degree of knowledge integration. These two dimensions capture key challenges of SESs research related to the need to account for context dependence and the intertwined nature of SESs as systems of humans embedded in nature across multiple scales, as well as to acknowledge different problem framings, understandings, interests, and values. We highlight the need to be aware of the potentials, limitations, and conceptual backgrounds underlying the different approaches. Critical engagement with modeling for different aims of SESs research can contribute to developing integrative understanding and action toward enhanced resilience and sustainability.
\end{abstract}

Key Words: adaptation; agent-based models; participatory modeling; structural realistic models; stylized or toy models; system dynamic models; transformation

\section{INTRODUCTION}

Understanding the dynamics that arise from the interactions and feedbacks between people, societies, and the ecosystems on which they depend is one of today's major challenges (Carpenter et al. 2009). Social-ecological systems (SESs) research is an emerging field that focuses on the interdependence between humans and nature that underlies many sustainability problems. Resilience thinking is a perspective used in SESs research that emphasizes the interdependent, complex, adaptive nature of humanenvironment systems and their nonlinear behavior, uncertainty, and surprise (Berkes and Folke 1998, Norberg and Cumming 2008, Folke et al. 2016). It emphasizes the need to understand and manage change, both in terms of withstanding shocks and disturbances through persistence and adaptation and also using them as an opportunity to change major characteristics of the system fundamentally when ecological, economic, or social structures make the existing system untenable, i.e., to transform (Folke et al. 2010). Resilience thinking thus goes beyond earlier notions of resilience as the capacity of the system to withstand shocks, and beyond a single focus on resilience as a system property or outcome. When we refer to SESs research here, we refer to research that takes a resilience thinking perspective.

Modeling played an important role in the early development of the concept of resilience, particularly in shifting the view of ecosystems as systems that evolve toward a single equilibrium to systems with multiple stable states (Holling 1973). Models of multiple stable states in ecosystems, and regime shifts or transitions between them, are still widely used today (e.g., Biggs et al. 2009, Scheffer et al. 2009, Hughes et al. 2017). In the past, models have also been used in the practice of adaptive ecosystem management such as in the Everglades, USA, particularly to assess the range of possible outcomes of management measures in complex systems (DeAngelis et al. 1998, Gunderson and Light 2006). Recent research about SESs and their governance from a resilience perspective, however, involves very little modeling. This is somewhat surprising, given recent developments of modeling in related fields such as ecology (Grimm and Railsback 2005), land system science (Matthews et al. 2007), environmental assessment and management (Kelly et al. 2013), and social simulation (Halbe et al. 2015). These developments include the proliferation of novel approaches from complexity science such as agent-based modeling (Filatova et al. 2013) and novel forms of model application such as participatory modeling to support societal learning and policy processes (Voinov et al. 2016).

One reason for the limited attention to modeling in resiliencebased SESs research may lie in the fragmentation of approaches across disciplines, which accompanies an often confusing diversity of purposes and model types, different underlying assumptions, problem foci, levels of analysis, and methodologies (Schlüter et al. 2012). Another reason may be an often rather narrow view of modeling among nonmodelers, based on experience with the use of simplistic economic models for policy

${ }^{1}$ Stockholm Resilience Centre, Stockholm University, Sweden, ${ }^{2}$ UFZ - Helmholtz Centre for Environmental Research Leipzig-Halle, Leipzig, Germany, ${ }^{3}$ University of Osnabrück, Institute for Environmental Systems Research, Osnabrück, Germany, ${ }^{4}$ German Centre for Integrative Biodiversity Research (iDiv) Halle-Jena-Leipzig, Leipzig, Germany 
support or complex biophysical models that follow a systems engineering tradition, both of which have limited applicability to the types of problems addressed by SESs research (Allison et al. 2018). Moreover, modeling adaptation and transformation of intertwined SESs is difficult and requires pushing modeling frontiers. Finally, the recognition of the context and path dependence of SES dynamics has resulted in a focus of resiliencebased SESs research on in-depth case studies that allow for rich, context-based understanding of resilience management or transformation challenges (e.g., Olsson et al. 2008, Gelcich et al. 2010).

Broadening the use of models and modeling in SESs research may help address the challenges for analysis and governance resulting from the intertwined, diverse, and complex adaptive nature of SESs. Although the importance of social-ecological relations and interactions has long been recognized, there is still a lack of tools for analyses that go beyond the separation of social and ecological to account for social-ecological relations and feedbacks. SESs are dynamic systems that continuously change and coevolve. Capturing the dynamics that arise from complex interactions across multiple scales to influence adaptation or transformation is another challenge to which different modeling approaches may contribute significantly. These challenges pose interesting research frontiers for the field of SES modeling itself (Schlüter et al. 2012, Filatova et al. 2016, Schulze et al. 2017). Thus, we believe that a deeper engagement of the SESs research community with dynamic modeling, and of the modeling community with recent developments in SESs research, can help advance the field and enhance the understanding and governance of SESs as complex adaptive systems.

Here, our aim is to take a step toward that deeper engagement and encourage the use of modeling for the analysis and governance of SESs by introducing SESs researchers to the most common types of models and applications of dynamic modeling relevant for SESs research, and by providing guidance for identifying the modeling approach most suitable for the aims of a given study or activity. To this end, we propose the reference scheme "ModSES" (modeling for social-ecological systems research), which aligns different SESs research aims with suitable model types and applications along the dimension of increasing realism, from theoretical study to empirical case, and along the degree of integration of different disciplines, stakeholders, and knowledge systems, from mono- to inter- and transdisciplinary. These dimensions capture two key challenges in dealing with complex and wicked sustainability problems: the need to account for context dependence; and the need to study SESs as integrated wholes where humans are embedded in ecosystems, not as separate social and ecological systems, and to take into account different, often contested, problem framings, understandings, interests, and values when developing solutions (Tengö et al. 2014). Although ModSES is intended for modelers and nonmodelers alike, we have particularly developed it to support collaboration between field researchers and modelers because these collaborations provide exciting opportunities for addressing these challenges.

We first review past modeling studies in resilience research to highlight the early uses of modeling. We do not review the increasing numbers of SES modeling studies since 2012 because that is beyond the scope of this paper and has been done elsewhere
(Schulze et al. 2017, Egli et al. 2019). Instead, we assess the use of different types of model and model applications in related fields that can support different types of overarching SESs research aims and challenges. The research aims and challenges reflect recent developments in resilience thinking, particularly the shift in focus from persistence toward adaptation and transformation, the importance of the intertwinedness of people and ecosystems, and the complex adaptive nature of these systems (Folke et al. 2016). We align these aims with different purposes of models and review commonly used model types in related fields that can serve the different purposes. The combination of a type of model, e.g., system dynamics or agent-based, with a degree of realism and degree of integration characterizes what we call a modeling approach. We align modeling approaches with SESs research aims within the reference scheme ModSES to guide their application for different SESs research activities. In our discussion of the potential of modeling for resilience thinking and SESs research, we highlight the need to move toward a broader use of models beyond scientific understanding to support communication and knowledge integration in inter- and transdisciplinary processes. We hope that ModSES will be a first step to help SESs researchers and people interested in using modeling to support adaptation and transformation processes to choose appropriate tools.

\section{PAST USE OF MODELING IN RESILIENCE RESEARCH}

Modeling played a seminal role in the early days of resilience studies in ecology and their extension to natural resource and ecosystem management (Holling 1973, Crépin 2007). Our review of 52 resilience modeling studies from 1998 to 2011 shows that most models were developed to understand and manage the persistence of ecological or natural resource systems to disturbance or change (Section 3, Table A1 in Appendix 1). The main aims of these studies were: to assess the persistence of a specific system, to identify persistence mechanisms, to develop methods and measures to analyze and quantify resilience, and to evaluate and develop management strategies. Models for management focused either on an exploration of impacts and trade-offs among different alternative management strategies or on finding optimal management strategies that maximize resilience and economic performance. Only four studies used modeling to understand and manage adaptation, and none addressed transformation. The latter has not changed much since 2012 (but see Zagaria et al. 2017).

The most common model purposes are understanding and decision or management support (Fig. A4a in Appendix 1). Models for understanding are mostly generic, equation-based models, whereas those for decision or managment comprise both generic models for the development of (optimal) management strategies or context-specific, often rule-based, models for assessing implications of alternative management strategies in particular case studies (Fig. A4b in Appendix 1). The prominence of generic models is in part a historical legacy of the origin of the first resilience models in theoretical ecology, or resource economics. Only approximately one-third of the studies use models that are specific to a case study. This situation limits their potential to address real world problems in which context-specific complex interactions determine system behavior. This low number may be an underestimate because case-specific models that have been used for the practice of adaptive (co-)management have rarely been reported in the scientific literature. 
Many models focus on ecological resilience to an anthropogenic driver without accounting for feedback from ecosystem change to human behavior. The very rudimentary representation of the social system in many early resilience models strongly limits the possibility to address the implications for resilience of socialecological feedbacks, for instance, the response of resource users to changes in ecosystem state. Where they have been addressed, e.g., in bioeconomic models that investigate optimal management strategies, they do so at a highly aggregate level such as the level of a social planner who has perfect foresight and they are generally prescriptive, i.e., they aim to determine optimal policies under extremely simplified assumptions, rather than trying to understand real-world dynamics. Feedbacks at the level of individual actors or organisms and feedbacks across levels or scales have largely not been addressed. The lack of inclusion of full feedback loops in SES models is still an issue in SES modeling today, as recently highlighted by Filatova et al. (2016) and Schulze et al. (2017). However, there are also promising developments of models that explicitly consider social-ecological feedbacks and resilience (Huber et al. 2013, Lade et al. 2013, 2015).

We provide more information on the selection of papers and their coding, as well as additional insights from the reviewed studies from 1998-2011, in Appendix 1. That information includes, e.g., the types of resources and social systems modeled, types of disturbances, inclusion of social-ecological feedbacks, and depth of model analysis.

\section{MODEL PURPOSES AND ROLES IN SUPPORT OF DIFFERENT SOCIAL-ECOLOGICAL SYSTEM RESEARCH AIMS}

Resilience thinking was introduced as a framework for the study and management of SESs that highlights the interplay between persistence and change across scales (Folke et al. 2010). Much empirical and conceptual research in recent years has focused on the capacity to transform toward more sustainable trajectories (e. g., Westley et al. 2013, Moore et al. 2014, Olsson et al. 2014). Increasing emphasis has been placed on the need to acknowledge the interdependence between people and the biosphere, and the complex adaptive nature of SESs (Folke et al. 2016). Resilience thinking, as a problem-oriented research field within sustainability science, has a strong emphasis on developing approaches and processes that support change in real-world, place-based, problem contexts. It also needs to build on disciplinary research and interdisciplinary frameworks to ensure conceptual soundness. Aims of SESs research thus span the whole range from generalization and theory building to on-the-ground support for transformative processes.

Along the tensions of addressing real-world problems and developing SESs theory through processes that integrate diverse knowledge systems and account for the complex and intertwined nature of SESs, we identify five overarching SESs research aims that may benefit from greater involvement of modeling: (1) to identify generic processes or principles that determine SES behavior, (2) to manage SESs as complex adaptive systems, (3) to understand the emergence of SES phenomena, (4) to generate transdisciplinary knowledge about social-ecological interactions and feedbacks, and (5) to support social learning and exploration of new pathways for societal transformation (Table 1). Aim 1 represents classical deductive ways of theory testing and building as practiced in economics or theoretical ecology applied to SESs research. Aim 2 addresses the challenges of managing complex adaptive SESs that are characterized by uncertainty, surprise, the potential for abrupt change, and unintended outcomes (Levin et al. 2013). Aim 3 relates to an increasing call for understanding SES outcomes as emerging from the microlevel actions and interactions of diverse human and nonhuman entities and processes by which they are constrained (Levin et al. 2013). This call includes identifying the complex causal processes that give rise to SESs outcomes such as resilience or adaptive governance (Biesbroek et al. 2017) and understanding the consequences for governance (as in aim 2). Aim 4 addresses the need to develop an integrative, transdisciplinary understanding and theories about social-ecological interactions and feedbacks to capture better the intertwined nature of SESs (Folke et al. 2016). Aim 5 represents work on SES governance and transformations, particularly research or activities that aim to support societal processes of transformation through action research, participatory processes, and other forms of stakeholder engagement.

These research aims have direct consequences for the purpose of the models used to address them. Models are always developed for a particular purpose (Kelly et al. 2013). This idea is important because the research or study aim and the associated research question (if applicable) determine the choice of the degree of realism a model should have, and thus, its complexity, as well as the degree to which it should build on scientific knowledge from one discipline, several, or a broader set of knowledge systems, including nonscientific ones. Both choices, about the degree of realism and the degree of integration, will influence the selection of system boundaries, the variables and processes that will be included in the model, how decisions will be made (based on theory, empirical data, or field observations), and how the model's validity will be evaluated. Common model purposes relevant for SESs research are system understanding, exploration, explanation, prediction, management support, communication, learning, and theory building (e.g., Kelly et al. 2013, Poile and Safayeni 2016).

Finally, models can play different roles within a research or participatory process, from serving as analytical, predictive, explanatory, or exploratory tools to providing a boundary object to bridge across the interface of theory and empirics (Baumgärtner et al. 2008) or science and society (Collier et al. 2011, Seidl 2015). Models can be prescriptive, aiming at identifying how SESs should be managed, or descriptive, aiming to describe, understand, and explain how SESs work. Classical roles of models are their use as tools for determining optimal management strategies or predicting the outcomes of management measures. Other roles that are increasingly common and possibly more useful in SESs research are serving as eyeopeners, as arguments in disputed problem situations, or as objects to create consensus (van Daalen et al. 2002). The same model purpose can be associated with different model roles; for instance, the purpose of a model can be to capture key processes of a resource management situation in a particular place. This model can serve as a tool for predicting the consequences of a management measure or as an eye-opener about the side-effects of a particular management action. Several roles can overlap. However, it is important to make sure a model is adapted for the role for which it is intended, in the same way as it should be 
Table 1. Social-ecological systems (SESs) research aims and corresponding model purposes and roles.

\begin{tabular}{|c|c|c|c|}
\hline SES research aim & Example & Purpose of model & Role of model \\
\hline $\begin{array}{l}\text { Identify generic processes } \\
\text { or principles that } \\
\text { determine SES behavior }\end{array}$ & $\begin{array}{l}\text { - Typologies or archetypes of SESs } \\
\text { - Principles of resilience } \\
\text { - Principles governing changes in SESs }\end{array}$ & $\begin{array}{l}\text { - Understanding and theory building } \\
\text { - Models aim to capture general system } \\
\text { behavior and are often based on theory; } \\
\text { generally not applied to specific systems, } \\
\text { but to a class of systems }\end{array}$ & Analytical tool \\
\hline $\begin{array}{l}\text { Manage SESs as complex } \\
\text { adaptive systems }\end{array}$ & $\begin{array}{l}\text { - Development of optimal, robust, or } \\
\text { adaptive management strategies that take } \\
\text { uncertainty, different time scales, and } \\
\text { nonlinear behavior of SESs into account }\end{array}$ & $\begin{array}{l}\text { - Exploration, management support, } \\
\text { prediction } \\
\text { - Models aim to explore or predict system } \\
\text { responses to policy or are used for } \\
\text { development of optimal or robust policy }\end{array}$ & Tool for forecasting or prediction \\
\hline $\begin{array}{l}\text { Understand the } \\
\text { emergence of SES } \\
\text { phenomena }\end{array}$ & $\begin{array}{l}\text { - Identification of micro-level social- } \\
\text { ecological processes and mechanisms } \\
\text { that give rise to macro-level SES } \\
\text { outcomes } \\
\text { - Understanding of interactions across } \\
\text { scale }\end{array}$ & $\begin{array}{l}\text { - Understanding and explanation } \\
\text { - Purpose of model is to explore system } \\
\text { behavior produced by complex } \\
\text { interactions between actors and } \\
\text { ecosystems; often based on empirical data; } \\
\text { often developed for a specific case study }\end{array}$ & $\begin{array}{l}\text { Tool for exploration and } \\
\text { explanation }\end{array}$ \\
\hline $\begin{array}{l}\text { Generate } \\
\text { transdisciplinary } \\
\text { knowledge about social- } \\
\text { ecological interactions } \\
\text { and feedbacks }\end{array}$ & $\begin{array}{l}\text { - Linking insights on human behavior } \\
\text { with insights on nonlinear ecological } \\
\text { dynamics to assess implications for } \\
\text { natural resource management } \\
\text { - Integrating insights on social and } \\
\text { institutional change with insights on } \\
\text { ecosystem dynamics to understand } \\
\text { transformation }\end{array}$ & $\begin{array}{l}\text { - Understanding, exploration, } \\
\text { communication, learning, theory building } \\
\text { - Purpose of model is to facilitate } \\
\text { integration of disciplinary knowledge } \\
\text { about ecological and social processes, test } \\
\text { competing hypotheses, and experiment } \\
\text { with a virtual system to enhance } \\
\text { understanding and build transdisciplinary } \\
\text { theory }\end{array}$ & $\begin{array}{l}\text { Tool for exploration and } \\
\text { experimentation; } \\
\text { Boundary object for } \\
\text { interdisciplinary knowledge } \\
\text { integration }\end{array}$ \\
\hline $\begin{array}{l}\text { Support social learning } \\
\text { and exploration of new } \\
\text { pathways for societal } \\
\text { transformation }\end{array}$ & $\begin{array}{l}\text { - Development of shared understanding } \\
\text { and solutions for a policy problem } \\
\text { - Development of a vision for a } \\
\text { sustainable future and strategies to get } \\
\text { there }\end{array}$ & $\begin{array}{l}\text { - Exploration, communication, learning } \\
\text { - Purpose of model or model building } \\
\text { process is to make explicit different system } \\
\text { understandings of stakeholders, explore } \\
\text { alternative development pathways, and } \\
\text { support social learning }\end{array}$ & $\begin{array}{l}\text { Tool for exploration or forecasting } \\
\text { (scenario analysis); } \\
\text { Boundary object, eye opener (van } \\
\text { Daalen et al. 2002), myth buster } \\
\text { (Smajgl and Ward 2015) }\end{array}$ \\
\hline
\end{tabular}

adapted to its purpose. An unreflected use of a model in a different role can be problematic.

To summarize, the aim of a given research project or activity determines the purpose of the model and its role in the scientific or participatory process. It also determines the degree of realism of the model, as well as the extent to which the model builds on inter-or transdisciplinary knowledge. We call the combination of a degree of realism of a model, the degree of integration of different knowledge in model design, and the type of model used, a "modelling approach". Next, we discuss different types of models commonly used in fields related to SESs research, and then explicate different degrees of realism that can be expressed with the different model types.

\section{COMMONLY USED MODEL TYPES IN RELATED FIELDS}

The numbers of model purposes and applications have increased with the development of new model types. The increase in computational power now allows for the design of complex, structurally realistic models. Different model types are more or less suitable for the different purposes and roles outlined above because they may lead to different choices regarding the tradeoffs among generality, realism, and precision (Levins 1966). Different model types also allow for different types of analysis and represent top-down or bottom-up views of a system. For instance, generic, analytical models have a high level of generality at the expense of realism, can be analyzed using mathematical methods such as stability analysis, and represent a top-down view of the system in which individual system elements are represented as averages (Table 2). In contrast, structurally realistic models are often highly realistic at the expense of generality, are analyzed through simulations and statistical techniques, and represent bottom-up views of the system that incorporate heterogeneity of system elements. Different model types also have their origin in different disciplines, which influences the basic underlying assumptions about system dynamics (e.g., systems in equilibrium vs. constantly changing), model structure (e.g., from first principles vs. empirical data and understanding), human behavior (e.g., rational actor vs. rule-based decision making), and level of abstraction (e.g., stocks vs. individual entities).

We draw on model-based research and activities in the fields of ecology, resource economics, land system science, computational social sciences, and participatory natural resource management to identify different model types suitable for supporting the research aims outlined in Table 1 (Table 2). We also build on earlier reviews of model types and purposes in related fields such as landuse and land-cover change (Parker et al. 2003), integrated assessment (Kelly et al. 2013), regime shifts (Filatova et al. 2016), and transition research (Halbe et al. 2015). We complement these studies by including an analysis of the disciplinary origins and conceptual and analytical basis of different model types and purposes because they are critical for understanding assumptions 
Table 2. Descriptions of model types.

\begin{tabular}{|c|c|c|c|c|c|}
\hline Type of model & $\begin{array}{l}\text { Origin or conceptual } \\
\text { foundation }\end{array}$ & Formalization & Analysis & Examples of application & Literature examples \\
\hline $\begin{array}{l}\text { Dynamical } \\
\text { systems models }\end{array}$ & $\begin{array}{l}\text { Physics, theoretical } \\
\text { ecology, economics }\end{array}$ & $\begin{array}{l}\text { System of differential or } \\
\text { difference equations } \\
\text { representing rate of change } \\
\text { of aggregate system variables }\end{array}$ & $\begin{array}{l}\text { Symbolical or } \\
\text { numerical analysis of } \\
\text { fixed points, stability, } \\
\text { attractors, } \\
\text { bifurcations }\end{array}$ & $\begin{array}{l}\text { Regime shifts, alternative } \\
\text { stable states }\end{array}$ & $\begin{array}{l}\text { Biggs et al. (2009), Scheffer } \\
\text { et al. (2009), Figueiredo } \\
\text { and Pereira (2011), Horan } \\
\text { et al. (2011), Tavoni et al. } \\
\text { (2012), Lade et al. (2017) }\end{array}$ \\
\hline $\begin{array}{l}\text { Bioeconomic } \\
\text { models }\end{array}$ & $\begin{array}{l}\text { Resource economics } \\
\text { (Clark 1990) }\end{array}$ & $\begin{array}{l}\text { Objective function } \\
\text { representing control variable } \\
\text { to be maximized given a } \\
\text { dynamic resource and } \\
\text { economic constraints }\end{array}$ & $\begin{array}{l}\text { Control theory, } \\
\text { optimization }\end{array}$ & $\begin{array}{l}\text { Optimal management of } \\
\text { resource with regime } \\
\text { shifts, response of } \\
\text { resource users to new } \\
\text { policy }\end{array}$ & $\begin{array}{l}\text { Smith and Wilen (2003), } \\
\text { Crépin (2007), Dowling et } \\
\text { al. (2012) }\end{array}$ \\
\hline $\begin{array}{l}\text { System } \\
\text { dynamics } \\
\text { models }\end{array}$ & $\begin{array}{l}\text { Organization } \\
\text { research (Sterman } \\
\text { 2001), environmental } \\
\text { studies (Forrester } \\
\text { 1994) }\end{array}$ & $\begin{array}{l}\text { Causal-loop diagrams, } \\
\text { differential or difference } \\
\text { equations representing rate } \\
\text { of change of aggregate } \\
\text { system variables }\end{array}$ & $\begin{array}{l}\text { Time-based } \\
\text { simulations, } \\
\text { simulation games }\end{array}$ & $\begin{array}{l}\text { Feedback analysis, } \\
\text { identification of leverage } \\
\text { points to change system } \\
\text { dynamics }\end{array}$ & $\begin{array}{l}\text { Carpenter and Gunderson } \\
(2001) \text {, Elsawah et al. } \\
(2017)\end{array}$ \\
\hline $\begin{array}{l}\text { State-and- } \\
\text { transition } \\
\text { models, Markov } \\
\text { chain models }\end{array}$ & $\begin{array}{l}\text { Ecology (Westoby } \\
\text { 1989), agricultural } \\
\text { economics }\end{array}$ & $\begin{array}{l}\text { Matrix of transition } \\
\text { probabilities of states }\end{array}$ & $\begin{array}{l}\text { Time-based } \\
\text { simulations, analysis } \\
\text { of emergent patterns } \\
\text { and structural change }\end{array}$ & $\begin{array}{l}\text { Resource use and regime } \\
\text { shifts in rangelands or } \\
\text { forests caused by natural } \\
\text { or human drivers such as } \\
\text { exploitation, fire, and } \\
\text { climate change }\end{array}$ & $\begin{array}{l}\text { Satake et al. (2008), } \\
\text { Zimmermann et al. (2009), } \\
\text { Bestelmeyer et al. (2017) }\end{array}$ \\
\hline $\begin{array}{l}\text { Structurally } \\
\text { realistic models }\end{array}$ & $\begin{array}{l}\text { Ecology (Grimm and } \\
\text { Railsback 2005), } \\
\text { social sciences } \\
\text { (Epstein 2006), } \\
\text { computer science }\end{array}$ & $\begin{array}{l}\text { Computational } \\
\text { representation of agents, } \\
\text { their properties, and } \\
\text { interactions with each other } \\
\text { and their environment }\end{array}$ & $\begin{array}{l}\text { Time-based } \\
\text { simulations, analysis } \\
\text { of emergent macro- } \\
\text { level patterns, } \\
\text { statistical analysis of } \\
\text { simulation data }\end{array}$ & $\begin{array}{l}\text { Emergent system-level } \\
\text { patterns and dynamics, } \\
\text { policy assessment taking } \\
\text { spatial structure and } \\
\text { agent diversity into } \\
\text { account }\end{array}$ & $\begin{array}{l}\text { Wiegand et al. (2003), } \\
\text { Filatova et al. (2011), } \\
\text { Grimm and Railsback } \\
\text { (2012), Smajgl and } \\
\text { Bohensky (2013) }\end{array}$ \\
\hline
\end{tabular}

that underlie each approach. Boundaries between model types are fuzzy, e.g., an agent-based model can also be formalized in difference equations, and model names can vary among disciplines. Major differences between model types are the level of aggregation (mathematical models often work with aggregate variables based on mean field approximation, whereas structural realistic models represent individual objects or agents and their interactions) and the methods used for solving the model (mathematical analysis vs. simulation over time).

Dynamical systems models, bioeconomic models, and system dynamics models are all based on dynamical systems theory, which is an area in mathematics that studies the behavior of complex dynamical systems. These models differ with respect to their construction, formalization, and analysis. Dynamical systems models are formalized as systems of differential equations that are analyzed to identify fixed points or steady states, assess their stability, and identify attractors, bifurcations, or tipping points. Models are often solved analytically, which strongly limits the numbers of variables and functions that can be included. Results are often presented graphically as state or phase-space diagrams. Dynamical systems models represent the system in a highly simplified and aggregate way, often building on well-known models from ecology such as the Lotka-Volterra predator-prey equations or from bioeconomics such as the Gordon-Schaeffer harvesting model (Gordon 1954). Their purpose is mostly to understand and predict general system behavior. Seminal work in ecology includes Holling's (1973) work on alternative stable states of ecosystems, as well as research on regime shifts, critical transitions, and early warning signals (e.g., Scheffer et al. 2009).
Further fields of application include the dynamics of a natural resource under technological and demographic change (Anderies 2003).

Bioeconomic models apply economic theory to natural resources, most commonly, fisheries. They are analyzed to identify optimal management strategies by maximizing a production function that uses a natural resource and effort or labor as inputs. An optimization approach is used to find the effort that maximizes the profits of a single owner or a social manager under the constraints of the dynamics of the natural resource. Bioeconomic models are also used to simulate the development of an economic system of natural resource use over time (instead of optimizing a control variable). Simulation-based bioeconomic models are similar to system dynamics models (described next), with a specific focus on economic processes. Bioeconomic approaches are very common for policy assessments in fisheries, e.g., the effect of the introduction of a marine reserve on resource users and ecological outcomes (e.g., Sanchirico and Wilen 2001, Smith and Wilen 2003, Dowling et al. 2012). Most bioeconomic models in fisheries only consider economic drivers of resource users' decisions (van Putten et al. 2012). The same situation holds for the use of bioeconomic models in agriculture, although models assuming multicriteria approaches exist (reviewed by Janssen and van Ittersum 2007).

System dynamics models are often constructed using causal loop diagrams, which represent feedbacks that are assumed to drive the dynamics of a system. These models are often analyzed graphically by identifying the feedbacks that stabilize the system 
(negative or balancing feedbacks) and those that destabilize it (positive or reinforcing feedbacks), and assessing their relative strengths (see Marzloff et al. 2011 for a reef ecosystems example). Causal loop diagrams and the stocks and flows on which they are based can also be formalized in simulation models in which the change of the system at each time step is represented using difference equations. System dynamics models are analyzed by simulating them over time and studying the resulting system-level behavior (e.g., Baur and Binder 2015) or assessing the implications of management or policy interventions (Elsawah et al. 2017). The differences among dynamical systems models mainly lie in the approaches to analyzing the models, e.g., mathematical analysis of fixed points or equilibria vs. simulation of system development over time, which may or may not result in stable states (Elsawah et al. 2017).

State-and-transition models are used to investigate and communicate landscape changes over time (Bestelmeyer et al. 2017). They are based on the assumptions that the ecosystem under consideration can exhibit multiple alternative states and that transitions between states take place with a certain probability. The transitions are typically driven by the interaction of succession, disturbance, and management, and can lead to irreversible states (Daniel and Frid 2012). This type of model has been applied to a number of management-related questions involving forests, rangelands, and wetlands. State-and-transition models are strongly related to empirical data. Conceptual stateand-transition models that use boxes-and-arrows diagrams have also proven to be helpful tools to integrate local knowledge and to support the generation of hypotheses in participatory processes (e.g., Knapp et al. 2011, Kachergis et al. 2013 for rangeland management) or for qualitatively comparing different management actions (e.g., Bestelmeyer et al. 2004 for fire vs. grazing processes in a rangeland system).

Structurally realistic models represent a system as composed of entities (human and nonhuman), their interactions, and the environment in which they are embedded. They take structural aspects such as spatial arrangements, heterogeneity of actors, or their interactions through (social) networks relevant for a given research question into account, often at two or more levels. Structural aspects and decision making of agents are often formalized via rule-based approaches ("if-then rules") or decision trees, which allow a more realistic mapping of relevant processes than possible in generic mathematical models. In ecology, structurally realistic models are often called individual-based models; in social simulation and environmental research, models that include human actors are called agent-based models. They are a powerful model type to generate a mechanistic and multilevel understanding of SESs. Models representing different hypotheses about possible mechanisms can be constructed and model outcomes can be tested against empirical data (DeAngelis and Mooij 2005) using pattern-oriented modeling (Grimm et al. 2005). They are grounded in a complexity perspective and allow for an abductive approach to science in which model construction is inspired by well-grounded assumptions or theories, and model analysis follows an inductive approach in which data are provided by simulations (Griffin 2006). Their computational nature facilitates the construction of models that are more realistic than dynamical systems models or bioeconomic models and, thus, are easier to link to real world problems (Berger and Schreinemachers
2006, Janssen and Ostrom 2006, Smajgl and Bohensky 2013, Schulze et al. 2017) but are also more difficult to analyze. However, structurally realistic models do not aim to be as realistic as possible; they include details only where they are considered relevant to answer a given research question.

\section{DEGREE OF REALISM OF A MODEL}

Each model type can be used to develop a model with different degrees of realism, but some are more suitable for generic representations and others for high degrees of realism. For the purpose of our analysis, we distinguish between (1) generic or theoretical models whose structure and assumptions on causal relations are based on (bio)economic or ecological theory, (2) stylized or toy models that are built to represent only selected aspects of a system in a stylized way for the purpose of investigating their impact on outcomes, and (3) empirical models whose structure, assumptions, and parameter values are based on information and data from a specific case. In reality, of course, the boundaries of the three classes are fuzzy; an empirical model will often also include assumptions that are based on theory, and a theoretical model may be inspired by or tested in a particular case. Toy models are often built on a mix of theoretical and empirically informed assumptions. Because they have become quite popular, particularly with agent-based modeling, we briefly describe stylized or toy models in more detail.

Stylized or toy models are "virtual laboratories" that facilitate computational experimentation with an SES in situations where policy experiments are not possible (Seppelt et al. 2009). They focus on a few, often hypothesized, aspects of a complex problem situation as a first step to enhance understanding of the behavior of a system. They are particularly useful in situations in which the quantitative knowledge base or the time frame available for model development is too limited for the development of structurally realistic models, or where a more complex model is too difficult and nontransparent to be well communicated to stakeholders. Their advantage lies in the possibility of exploring the consequences of different assumptions about socialecological feedbacks and possible ecological and human responses. In such settings, toy models can serve as thought experiments for rapid development and testing of hypotheses to inform a field campaign (Turner 2003), to explore new strategies and development pathways, or to develop a model prototype to generate new hypotheses that can be tested later in more structurally rich models (Müller et al. 2011). For instance a toy model can be used to assess the potential and risks of new institutions, taking the response of the affected users into account. Management strategy evaluation, as applied to conservation, uses toy models to assess different types of uncertainties and their implications for wildlife management (Milner-Gulland 2011). Van Poorten et al. (2011) used a toy model of recreational fisheries to demonstrate how the panacea of stocking can emerge from management actions of bounded rational actors in a variable environment. These models can also serve as tools for communication and integration of different conceptual backgrounds and perspectives, as a basis for the development of management strategies (Daw et al. 2015).

The degree of realism needed for a given modeling study is a dimension well known to environmental modelers. Of particular interest here is the need to navigate the tension between the context 
dependence of social-ecological phenomena and the need to find generalizable insights to support management and governance.

\section{LINKING RESEARCH AIMS WITH MODELING APPROACHES: THE REFERENCE SCHEME "ModSES"}

The reference scheme ModSES delineates a space to map different research aims and align them with suitable modeling approaches. Each research aim and model type is mapped according to the degree of realism and degree of integration that models in support of this aim should incorporate (Fig. 1). The tensions between generality and realism and between science and society are struggles that different environmental modeling communities have faced for decades. Modeling studies aimed at addressing the former cover a range from theoretical to case-based research that differ with respect to the levels of abstraction and aggregation of relevant entities and interactions or processes (Baumgärtner et al. 2008). Studies addressing the latter are concerned with the complexities and context dependence of specific problem situations as well as the need to take into account different knowledge systems and coproduce knowledge with stakeholders (Tengö et al. 2014). The nature of these tensions is the same for SESs research, but with some important nuances related to the complexity and intertwined nature of SESs, where humans and ecosystems coconstitute and affect each other across all scales (Folke et al. 2016). This situation requires a focus on socialecological relations and interactions as the core processes determining outcomes, which significantly goes beyond an ecological model that incorporates human action as a driver, or an economic model that regards ecosystems as an input to a production function (Schlüter et al. 2012). This focus on interdependence poses additional challenges for the degree of integration and the degree of realism because social-ecological relations can play out differently in different contexts.

Fig. 1. The reference frame "modeling for social-ecological systems research" (ModSES). The gray area indicates the location of stylized or toy models, which can be built using different model types. SES = social-ecological system.

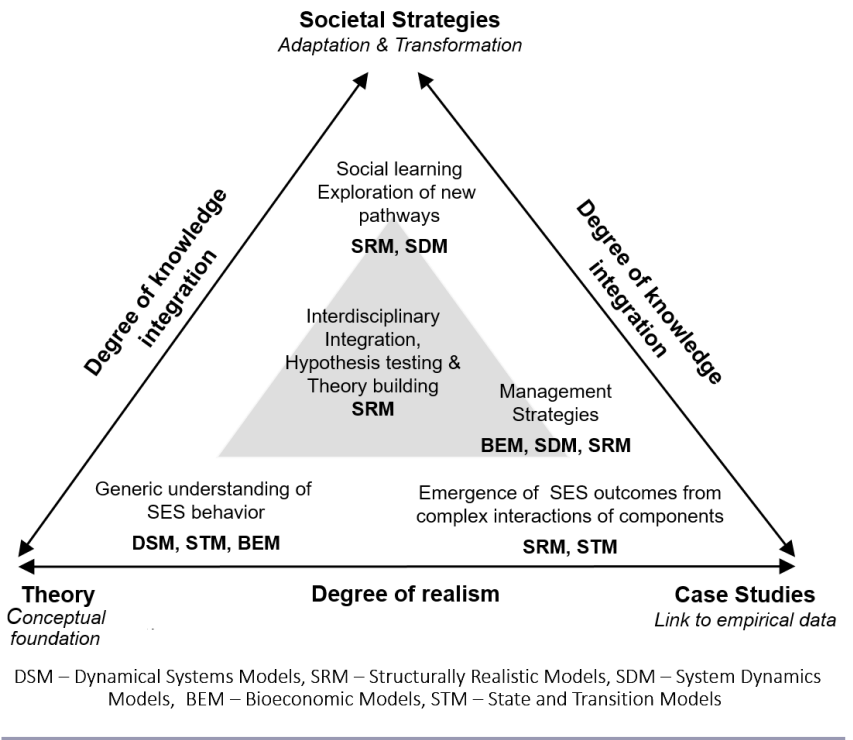

Erratum: In the original publication of Figure $1 \mathrm{a}$ label on the $\mathrm{x}$ axis was missing. The omission was corrected on 8 May 2019.
Our alignment of research aims with model types, degrees of integration, and realism is based on an assessment of the characteristics of different model types and a review of their use in other disciplines. Additionally, it is informed by many years of the authors' modeling experience in ecology, environmental systems, natural resource management, SESs, and participatory processes using all types of models highlighted here. When assessing the suitability of a model type for a research aim, the following two criteria are of importance. First, the research aim and research question determine the level of aggregation of the elements in the model (e.g., subsystem, aggregate variable, or individual agent) and level of realism needed in a model. Different types of models allow different levels of aggregation and realism; for example, a dynamical systems model cannot incorporate individual characteristics of actors or organisms and is very restricted with respect to its complexity because of the mathematical analyses used to identify fixed points and their stability. In contrast, a structurally realistic model disaggregates a SES into agents (individual or collective actors such as farmers or households or tree functional groups) and their interactions with each other and their environment. That type of model can be implemented with a high degree of realism as an empirical model that is parameterized with empirical data or as a toy model that is based on hypotheses about agent interactions that may be informed by empirical observations or theory. These models, however, can only be analyzed through statistical analysis of the outcomes of time-based simulations.

Second, some types of model have been used more commonly for specific research aims than others. For example, dynamical systems models have rarely been used for participatory modeling, whereas structurally realistic models are rarely used for theory testing. Finally, models can be predictive or explorative, and descriptive or prescriptive, which influences the choice of model type for a study or application. If the purpose of a model is to identify an optimal management strategy for a fishery, a prescriptive bioeconomic model solved to maximize a utility function will be most suitable. If the purpose is to understand how the diversity of human behavior affects the outcomes of a fishery, the choice will be a descriptive structural realistic model that enables representation of heterogeneous fishers and their interactions with fish stocks.

At the lower left corner of ModSES (Fig. 1) lies the aim to identify generic processes or principles that determine SES behavior, which is often supported by dynamical systems models, bioeconomic models, or theoretical state-and-transition models, which generally rely on theory and methods from the respective disciplines, particularly ecology and economics. This modeling use has been one of the most common in early resilience research, building on Holling's (1973) seminal work on the stability of ecosystems, and a large body of research on critical transitions (Scheffer et al. 2001, 2009, Brock and Carpenter 2006). These models are predominantly developed and used by scientists.

At the other end of the horizontal axis in the lower right corner (Fig. 1), one can find structurally realistic models or state-andtransition models, which are based on knowledge and data from a particular place such as a landscape (Spies et al. 2017) or a fishery (Libre et al. 2015). Structurally realistic models or stateand-transition models have a high degree of realism, with the aim 
of understanding the emergence of SES outcomes from local interactions or from changes in state of its components, respectively. These models are often used to explore the effect of policies (e.g., Daloğlu et al. 2014 for agriculture, Bino et al. 2015 for floodplain management, Thulke et al. 2018 for animal diseases) or the future development of the SES under climate change or other external disturbances (Millington et al. 2008 for wildfire). These models often capture structural details of a particular setting such as spatial patterns or social or ecological networks in a bottom-up manner using empirical data from the case study. Structurally realistic models such as agent-based models are particularly suitable to capture spatial aspects of the studied SES (Filatova et al. 2013). The development of these detailed case-based models is carried out by scientists, often from a specific discipline such as landscape ecology, but can include data collected through stakeholder interviews, surveys, or focus group discussions.

When moving along the vertical axis toward the middle-right of the ModSES triangle (Fig. 1), modeling purposes change from a primary focus on understanding to a focus on policy, management, and decision support. In addition, the degree of inclusion in model development or analysis increases for different domain experts and stakeholders. The use of models to support management is one of the most common uses of modeling in environmental research and is increasingly used in SESs research (e.g., Chapin et al. 2003, Schouten et al. 2013). Models for management are often developed for a specific case study but their degree of realism can vary greatly. Bioeconomic models apply economic theory to particular cases to determine optimal management strategies (Anderies et al. 2002, Crépin 2007); in contrast, structurally realistic models test the consequences of different management strategies, taking the complex adaptive nature of SESs into account (e.g., Little et al. 2009, Walsh and Mena 2016). System dynamics models are also a common model type that can include more realism than bioeconomic models but still model the system at an aggregate level in which system dynamics are represented as stocks and flows. In these modeling approaches, stakeholders are sometimes involved as experts to inform model structure, identify management priorities, or prioritize management measures and rank outcomes (e.g., Reichert et al. 2013).

In the middle-left of the ModSES triangle (Fig. 1), we find research aims related to the development of inter- or transdisciplinary understanding and theory of SESs. Models and the modeling processes can be useful tools to support socialecological integration in inter- or transdisciplinary processes (Nicolson et al. 2002, Lade et al. 2015). Structurally realistic models that have a degree of realism characterized as stylized or toy models are common tools for this research aim (gray area in Fig. 1). Their realistic but selective representation of real systems makes them simple enough to be developed quickly and to serve as a tool for exploring different hypotheses about causal relationships. They thus allow for rapid prototyping and experimentation within an iterative process of model development and empirical research. They can support interdisciplinary knowledge integration through a process of codevelopment of the model by representatives of different disciplines. This process requires participants to define the concepts they use and make explicit their understanding and assumptions about the SES (Nicolson et al. 2002, Olson et al. 2008), thus facilitating integration of knowledge on ecological and social factors and dynamics of the studied SES phenomena (e.g., Lade et al. 2015). However, given their simplistic nature, toy models are often difficult to validate and thus should be used in a larger context of field and experimental studies or an adaptive management process.

Lastly, the use or codevelopment of models in participatory processes (participatory modeling) has become a widely used method in environmental assessment and natural resource management (Voinov et al. 2016), with the aim of supporting social learning and the exploration of alternative development pathways through scenario analysis (e.g., Carpenter et al. 2015). Models in participatory processes can serve as boundary objects (Mollinga 2010) that help reveal differences in problem framing, values, and goals, and can help to enhance transparency, build trust, and facilitate communication on complex SES relationships (Campo et al. 2010). However, the process and context of the development and use of models in participatory processes, as well as their integration into the larger decision-making process, are critically important for their success (Lynam et al. 2007). There are a range of goals for participatory modeling: (1) using a participatory process to increase the real-world impact to modeling; (2) enhancing system understanding and problem perceptions of participants, e.g., to recognize trade-offs and potential conflicts and develop strategies to resolve them, thus enhancing problem-solving capacity (Sandker et al. 2010, Dumrongrojwatthana and Trébuil 2011); (3) facilitating exploration of likely social-ecological consequences of decisions, (4) supporting communication and learning among participants; (5) coproducing a model to achieve a problem definition that is relevant to the diversity of stakeholder values in a system; and (6) supporting conflict resolution (Lynam et al. 2007, Prell et al. 2007, Voinov and Gaddis 2008, Smajgl 2010). A range of different model types are used, with agent-based or system dynamics models being most prominent. Models can either be brought into the participatory process by scientists or be codeveloped with stakeholders to represent their system understanding and problem perception (also called mediated modeling or companion modeling; van den Belt 2004, Etienne 2012). Often, they are combined with role-playing games, a combination that has been shown to facilitate problem solving and relational learning in complex problem situations such as river basin management (Gurung et al. 2006, Stefanska et al. 2011).

\section{DISCUSSION}

ModSES is intended as a tool to help modelers, nonmodelers, students, policy makers, and other stakeholders interested in using models or modeling for SESs research to navigate the diversity of model types as well as model building and application processes used in SESs research and related fields. It can be used to create awareness of the different modeling purposes and help guide or justify the selection of a particular model type. It also facilitates communicating a chosen approach and application to other researchers and stakeholders by situating it along two dimensions: generality-realism and science-society. The two axes of ModSES merge at the top, indicating that approaches supporting societal processes of adaptation and transformation need to incorporate sufficient realism and be of a transdisciplinary nature. For instance, strategy development and social learning can greatly 
benefit from the use of place-based modeling approaches that aim to unravel causal mechanisms operating in a specific context. There is also a need to generalize from individual cases in a way that does justice to the importance of context, i.e., by developing contextualized generalizations. Such an understanding of key mechanisms at play in different contexts can provide valuable insights about entry points for governance. Ultimately, there will and should always be studies situated at different locations along these two dimensions, depending on the purpose of the model or the larger study in which it is embedded. A study may also include several different model types to address different aspects of the SES or stakeholder needs and to benefit from different insights into the problem they may provide. The usefulness of modeling studies can, however, be significantly enhanced when the choices of degree of realism and degree of integration are well documented and justified, and when researchers are aware of the possibilities and limitations of each approach.

ModSES is intended to be neither comprehensive nor exclusive with respect to the types of models included or how to map them onto the different research aims. Other combinations are possible and likely, e.g., a dynamical systems model with low degree of realism but high degree of integration used for social learning; however, they are less common and sometimes may be incompatible because of conflicts in underlying assumptions. Other modelers may disagree with some of our choices based on different experiences and interpretations with regard to which models are most appropriate for which research aim. Nevertheless, we believe that the scheme is useful for providing an orientation and guide about different possibilities of modeling in support of SESs research, particularly for those interested in developing their first model or collaborating with modelers. We have encountered much confusion with respect to what a model is and can or cannot do. We hope that ModSES will provide some clarity and a tool through which modelers can explain their models and how and for what purposes they can be applied.

The choice of a modeling approach is also a choice of a conceptualization of the system of interest that will influence the types of possible outcomes and the suitability of the approach for a given task. The different model types have their origin in different disciplines or research areas, which have different ontologies, epistemologies, and methodologies. An understanding of the conceptual foundations and system understanding associated with a type of model is thus essential for a sensitive use of the different approaches. Models that are based on dynamical systems theory such as bioeconomic models, for instance, are generally based on a view that the heterogeneity of system components can adequately be represented by averages or representative individuals such as a representative agent. Models that are based in complexity theory such as agent-based models are based on the view that heterogeneity and local adaptation are important for system-level outcomes and that human decision making is boundedly rational or follows other decision-making models.

The choice of the level of aggregation for a model, whether elements can be represented as aggregate stocks or as individual entities, matters whenever spatial structure or heterogeneity of entities may influence outcomes. Railsback and Harvey (2011) used a structurally realistic model to show that common theories of food limitation for animal populations do not hold when individual behavior of organisms is taken into account. Their model of fish populations that included habitat complexity and fish physiology revealed that active behavior of fish causes positive feedbacks that sustain food limitation despite an increase in food availability. This result can have important implications for conservation strategies. Structurally realistic models have also proven useful to reveal the effect of social heterogeneity on the dynamics of SESs, for example, the effect of agents' heterogeneity on the outcome of policy interventions (Smajgl and Bohensky 2013).

Models are simplified representations of reality in which the process of simplification is guided by the knowledge and assumptions of those involved in the model development process. Model results should always be interpreted in light of these assumptions and the underlying system conceptualization. The documentation of assumptions and choices made when implementing an approach and a discussion of limitations are thus of utmost importance. Recently, several tools have been developed to support more transparency on modeling choices (Grimm et al. 2006, Müller et al. 2013, Schlüter et al. 2014). Model assumptions are also critical for the applicability of a model for policy support. For instance, the choices about how to model human behavior have implications for the design of policies because the response of resource users to policy determines its effectiveness (Fulton et al. 2011). Models are increasingly being used to test consequences for SES outcomes of alternative assumptions about human behavior (Janssen 2016, Beckage et al. 2018) or social-ecological relations (Lade et al. 2017) to understand better the uncertainty associated with the complexity of human behavior and biophysical processes.

Many challenges remain to realizing the full potential of modeling for analysis and governance of SESs. Our review of past resilience modeling studies shows that many models lack links to the real world, which reflects the difficulty of building empirically based models of truly interdependent SESs, particularly with regard to integrating social science with natural science concepts and data and accounting for different levels of analysis (Janssen and Ostrom 2006, Smajgl and Barreteau 2014). Combinations of different model types in hybrid models, e.g., dynamical systems models with agent-based models, are a way forward to address different levels of aggregation and make use of the strengths of several approaches (Martin and Schlüter 2015). New modeling approaches have also recently been developed that are promising for the development of integrative empirical models of regime shifts using generalized modeling (Lade et al. 2015, Lade and Niiranen 2017) or the dynamics of social networks (Wiedermann et al. 2015). However, there remains a dilemma for policy support because models that are aimed to predict or optimize often do not account for complex social-ecological interactions, whereas those that capture social-ecological interdependence are normally not intended for prediction (Allison et al. 2018).

Two major challenges of SESs research in which a broadened use of modeling may be particularly interesting are the development of generalizable insights that do justice to the context dependence of social-ecological processes, and the development of understanding and theory of SESs that is truly integrative and builds on bridging between disciplines and knowledge systems to 
capture social-ecological interactions and feedbacks across scales and develop strategies for transformation. The lack of models of transformation itself (not modeling to support transformation) may reflect the difficulty of modeling systemic reorganization (Polhill et al. 2016). This is an interesting research frontier for SES modeling, particularly with respect to how models can help identify social-ecological mechanisms of transformation in complex and continuously changing SESs and generalize beyond single case studies. One of the largest benefits of models in SES research, however, may actually be their potential as process tools whereby they serve as boundary objects to challenge thinking in disciplinary silos, and explicate differences in values, worldviews, and understanding between different knowledge systems, and thus, help to move toward more integrated understanding and the development of widely accepted and co-owned solutions. Particularly, simple inter- and transdisciplinary toy models may be of use to address wicked problems for which traditional disciplinary or systems engineering models fail (Allison et al. 2018).

We believe that critical engagement with modeling for different aims of SESs research can contribute to developing integrative understanding and action toward enhanced resilience and sustainability. However, it is crucial that modeling is part of a larger process that involves, depending on the purpose, field studies, experiments, and participatory processes. Each part of the process highlights different aspects of the SES and involves different data and knowledge sources, and can thus jointly create a more differentiated and maybe adequate picture of the problem at stake. When based on the plurality of methods and applied in a larger process, modeling for SESs analysis, in our view, has the potential to significantly enhance the scientific basis for the governance of complex SESs and to support knowledge integration and social learning for the development of strategies and policies for SES governance. ModSES is a first step to encourage and provide guidance for the use of models and modelbuilding processes involving modelers and nonmodelers as a tool to address sustainability problems in SESs.

Responses to this article can be read online at: http://www.ecologyandsociety.org/issues/responses. php/10716

\section{Acknowledgments:}

We thank Volker Grimm for fruitful discussions and comments throughout the development of the manuscript. We thank Gunnar Dressler for support with data collection and first evaluation of the resilience models. Sten Zeibig contributed substantially to the analysis of the resilience models at an earlier stage of the project. We thank the participants of the workshop on modeling for resilience thinking and ecosystem stewardship at the 6th Biannual Conference of the International Society for Environmental Modeling and Software (IEMSS) in Leipzig 2012 for their critical comments and contributions. Comments from Örjan Bodin helped to improve an earlier version of the manuscript. MS acknowledges funding by the European Research Council under the European Union's Seventh Framework Programme (FP/2007-2013)/ERC grant agreement
283950 SES-LINK, the European Union's Horizon 2020 research and innovation programme (grant agreement 682472 -- MUSES), and a core grant to the Stockholm Resilience Centre by Mistra. Financial support from the DFG (German Research Foundation) in the framework of the Collaborative Research Centre 586 "Difference and Integration" (Universities of Leipzig and Halle) is gratefully acknowledged by BM and KF. BM was supported by the German Federal Ministry of Education and Research (BMBF - 01LN1315A) within the Junior Research Group POLISES.

\section{LITERATURE CITED}

Allison, A. E. F., M. E. Dickson, K. T. Fisher, and S. F. Thrush. 2018. Dilemmas of modelling and decision-making in environmental research. Environmental Modelling \& Software 99:147-155. http://dx.doi.org/10.1016/j.envsoft.2017.09.015

Anderies, J. M. 2003. Economic development, demographics, and renewable resources: a dynamical systems approach. Environment and Development Economics 8(2):219-246. http://dx.doi. org/10.1017/S1355770X0300123

Anderies, J. M., M. A. Janssen, and B. H. Walker. 2002. Grazing management, resilience, and the dynamics of a fire-driven rangeland system. Ecosystems 5(1):23-44. http://dx.doi. org/10.1007/s10021-001-0053-9

Baumgärtner, S., C. Becker, K. Frank, B. Müller, and M. Quaas. 2008. Relating the philosophy and practice of ecological economics: the role of concepts, models, and case studies in interand transdisciplinary sustainability research. Ecological Economics 67(3):384-393. http://dx.doi.org/10.1016/j. ecolecon.2008.07.018

Baur, I., and C. R. Binder. 2015. Modeling and assessing scenarios of common property pastures management in Switzerland. Ecological Economics 119:292-305. http://dx.doi.org/10.1016/j. ecolecon.2015.09.019

Beckage, B., L. J. Gross, K. Lacasse, E. Carr, S. S. Metcalf, J. M. Winter, P. D. Howe, N. Fefferman, T. Franck, A. Zia, A. Kinzig, and F. M. Hoffman. 2018. Linking models of human behaviour and climate alters projected climate change. Nature Climate Change 8:79-84. http://dx.doi.org/10.1038/s41558-017-0031-7

Berger, T., and P. Schreinemachers. 2006. Creating agents and landscapes for multiagent systems from random samples. Ecology and Society 11(2):19. http://dx.doi.org/10.5751/ES-01736-110219

Berkes, F., and C. Folke, editors. 1998. Linking social and ecological systems: management practices and social mechanisms for building resilience. Cambridge University Press, Cambridge, UK.

Bestelmeyer, B. T., A. Ash, J. R. Brown, B. Densambuu, M. Fernández-Giménez, J. Johanson, M. Levi, D. Lopez, R. Peinetti, L. Rumpff, and P. Shaver. 2017a. State and transition models: theory, applications, and challenges. Pages 303-345 in D. D. Briske, editor. Rangeland systems: processes, management and challenges. Springer, Cham, Switzerland. http://dx.doi. org/10.1007/978-3-319-46709-2

Bestelmeyer, B. T., J. E. Herrick, J. R. Brown, D. A. Trujillo, and K. M. Havstad. 2004. Land management in the American Southwest: a state-and-transition approach to ecosystem 
complexity. Environmental Management 34(1):38-51. http://dx. doi.org/10.1007/s00267-004-0047-4

Biesbroek, R., J. Dupuis, and A. Wellstead. 2017. Explaining through causal mechanisms: resilience and governance of socialecological systems. Current Opinion in Environmental Sustainability 28:64-70. http://dx.doi.org/10.1016/j.cosust.2017.08.007

Biggs, R., S. R. Carpenter, and W. A. Brock. 2009. Turning back from the brink: detecting an impending regime shift in time to avert it. Proceedings of the National Academy of Sciences 106 (3):826-831. http://dx.doi.org/10.1073/pnas.0811729106

Bino, G., S. A. Sisson, R. T. Kingsford, R. F. Thomas, and S. Bowen. 2015. Developing state and transition models of floodplain vegetation dynamics as a tool for conservation decision-making: a case study of the Macquarie Marshes Ramsar wetland. Journal of Applied Ecology 52(3):654-664. http://dx.doi. org/10.1111/1365-2664.12410

Brock, W. A., and S. R. Carpenter. 2006. Variance as a leading indicator of regime shift in ecosystem services. Ecology and Society 11(2):9. http://dx.doi.org/10.5751/ES-01777-110209

Campo, P. C., F. Bousquet, and T. R. Villanueva. 2010. Modelling with stakeholders within a development project. Environmental Modelling \& Software 25(11):1302-1321. http://dx.doi.org/10.1016/ j.envsoft.2010.01.005

Carpenter, S. R., E. G. Booth, S. Gillon, C. J. Kucharik, S. Loheide, A. S. Mase, M. Motew, J. Qiu, A. R. Rissman, J. Seifert, E. Soylu, M. Turner, and C. B. Wardropper. 2015. Plausible futures of a social-ecological system: Yahara watershed, Wisconsin, USA. Ecology and Society 20(2):10. http://dx.doi. org/10.5751/ES-07433-200210

Carpenter, S. R., and L. H. Gunderson. 2001. Coping with collapse: ecological and social dynamics in ecosystem management: like flight simulators that train would-be aviators, simple models can be used to evoke people's adaptive, forwardthinking behavior, aimed in this instance at sustainability of human-natural systems. Bioscience 51(6):451-457. https://doi. org/10.1641/0006-3568(2001)051[0451:CWCEAS]2.0.CO;2

Carpenter, S. R., H. A. Mooney, J. Agard, D. Capistrano, R. S. DeFries, S. Díaz, T. Dietz, A. K. Duraiappah, A. Oteng-Yeboah, H. M. Pereira, C. Perrings, W. V. Reid, J. Sarukhan, R. J. Scholes, and A. Whyte. 2009. Science for managing ecosystem services: beyond the Millennium Ecosystem Assessment. Proceedings of the National Academy of Sciences 106(5):1305-1312. http://dx. doi.org/10.1073/pnas.0808772106

Chapin, F. S. III, T. S. Rupp, A. M. Starfield, L. DeWilde, E. S. Zavaleta, N. Fresco, J. Henkelman, and A. D. McGuire. 2003. Planning for resilience: modeling change in human-fire interactions in the Alaskan boreal forest. Frontiers in Ecology and the Environment 1(5):255-261. http://dx.doi.org/10.1890/1540-9295 (2003)001[0255:PFRMCI]2.0.CO;2

Clark, C. W. 1990. Mathematical bioeconomics: the optimal management of renewable resources. Second edition. Wiley, New York, New York, USA.

Collier, N., B. M. Campbell, M. Sandker, S. T. Garnett, J. Sayer, and A. K. Boedhihartono. 2011. Science for action: the use of scoping models in conservation and development. Environmental Science \& Policy 14(6):628-638. http://dx.doi.org/10.1016/j. envsci.2011.05.004

Crépin, A.-S. 2007. Using fast and slow processes to manage resources with thresholds. Environmental and Resource Economics 36(2):191-213. http://dx.doi.org/10.1007/s10640-006-9029-8

Daloğlu, I., J. I. Nassauer, R. L. Riolo, and D. Scavia. 2014. Development of a farmer typology of agricultural conservation behavior in the American Corn Belt. Agricultural Systems 129:93-102. http://dx.doi.org/10.1016/j.agsy.2014.05.007

Daniel, C. J., and L. Frid. 2012. Predicting landscape vegetation dynamics using state-and-transition simulation models. Pages 5-22 in B. K. Kerns, A. J. Shlisky, and C. J. Daniel, editors. Proceedings of the First Landscape State-and-Transition Simulation Modeling Conference, June 14-16, 2011. General Technical Report PNW-GTR-869. United States Department of Agriculture, Forest Service, Pacific Northwest Research Station, Portland, Oregon, USA. [online] URL: https://www.fs.fed.us/ pnw/pubs/pnw gtr869.pdf

Daw, T. M., S. Coulthard, W. W. L. Cheung, K. Brown, C. Abunge, D. Galafassi, G. D. Peterson, T. R. McClanahan, J. O. Omukoto, and L. Munyi. 2015. Evaluating taboo trade-offs in ecosystems services and human well-being. Proceedings of the National Academy of Sciences 112(22):6949-6954. http://dx.doi.org/10.1073/ pnas. 1414900112

DeAngelis, D. L., L. J. Gross, M. A. Huston, W. F. Wolff, D. M. Fleming, E. J. Comiskey, and S. M. Sylvester. 1998. Landscape modeling for Everglades ecosystem restoration. Ecosystems 1 (1):64-75. http://dx.doi.org/10.1007/s100219900006

DeAngelis, D. L., and W. M. Mooij. 2005. Individual-based modeling of ecological and evolutionary processes. Annual Review of Ecology, Evolution, and Systematics 36:147-168. http:// dx.doi.org/10.1146/annurev.ecolsys.36.102003.152644

Dowling, N. A., C. Wilcox, M. Mangel, and S. Pascoe. 2012. Assessing opportunity and relocation costs of marine protected areas using a behavioural model of longline fleet dynamics. Fish and Fisheries 13(2):139-157. http://dx.doi.org/10.1111/ j.1467-2979.2011.00422.X

Dumrongrojwatthana, P., and G. Trébuil. 2011. Northern Thailand case: gaming and simulation for co-learning and collective action; companion modelling for collaborative landscape management between herders and foresters. Pages 191-219 in A. van Paassen, J. van den Berg, E. Steingröver, R. Werkman, and B. Pedroli, editors. Knowledge in action: the search for collaborative research for sustainable landscape development. Wageningen Academic, Wageningen, The Netherlands. [online] URL: $\underline{\text { http://dx.doi.org/10.3920/978-90-8686-724-0 }}$

Egli, L., H. Weise, V. Radchuk, R. Seppelt, and V. Grimm. 2019. Exploring resilience with agent-based models: state of the art, knowledge gaps and recommendations for coping with multidimensionality. Ecological Complexity, in press. https://doi. org/10.1016/j.ecocom.2018.06.008

Elsawah, S., S. A. Pierce, S. H. Hamilton, H. van Delden, D. Haase, A. Elmahdi, and A. J. Jakeman. 2017. An overview of the system dynamics process for integrated modelling of socio- 
ecological systems: lessons on good modelling practice from five case studies. Environmental Modelling \& Software 93:127-145. http://dx.doi.org/10.1016/j.envsoft.2017.03.001

Epstein, J. M. 2006. Growing artificial societies: social science from the bottom up. Princeton University Press, Princeton, New Jersey, USA.

Etienne, M., editor. 2012. Companion modelling: a participatory approach support sustainable development. Éditions Quae, Versailles, France.

Figueiredo, J., and H. M. Pereira. 2011. Regime shifts in a socioecological model of farmland abandonment. Landscape Ecology 26(5):737-749. http://dx.doi.org/10.1007/s10980-011-9605-3

Filatova, T., J. G. Polhill, and S. van Ewijk. 2016. Regime shifts in coupled socio-environmental systems: review of modelling challenges and approaches. Environmental Modelling \& Software 75:333-347. http://dx.doi.org/10.1016/j.envsoft.2015.04.003

Filatova, T., P. H. Verburg, D. C. Parker, and C. A. Stannard. 2013. Spatial agent-based models for socio-ecological systems: challenges and prospects. Environmental Modelling \& Software 45:1-7. http://dx.doi.org/10.1016/j.envsoft.2013.03.017

Filatova, T., A. Voinov, and A. van der Veen. 2011. Land market mechanisms for preservation of space for coastal ecosystems: an agent-based analysis. Environmental Modelling \& Software 26 (2):179-190. http://dx.doi.org/10.1016/j.envsoft.2010.08.001

Folke, C., R. Biggs, A. V. Norström, B. Reyers, and J. Rockström. 2016. Social-ecological resilience and biosphere-based sustainability science. Ecology and Society 21(3):41. http://dx.doi.org/10.5751/ ES-08748-210341

Folke, C., S. R. Carpenter, B. Walker, M. Scheffer, T. Chapin, and J. Rockström. 2010. Resilience thinking: integrating resilience, adaptability and transformability. Ecology and Society 15(4):20. http://dx.doi.org/10.5751/ES-03610-150420

Forrester, J. W. 1994. System dynamics, systems thinking, and soft OR. System Dynamics Review 10(2-3):245-256. http://dx.doi. org/10.1002/sdr.4260100211

Fulton, E. A., A. D. M. Smith, D. C. Smith, and I. E. van Putten. 2011. Human behaviour: the key source of uncertainty in fisheries management. Fish and Fisheries 12(1):2-17. http://dx.doi. org/10.1111/j.1467-2979.2010.00371.X

Gelcich, S., T. P. Hughes, P. Olsson, C. Folke, O. Defeo, M. Fernández, S. Foale, L. H. Gunderson, C. Rodríguez-Sickert, M. Scheffer, R. S. Steneck, and J. C. Castilla. 2010. Navigating transformations in governance of Chilean marine coastal resources. Proceedings of the National Academy of Sciences 107 (39):16794-16799. http://dx.doi.org/10.1073/pnas.1012021107

Gordon, H. S. 1954. The economic theory of a common-property resource: the fishery. Journal of Political Economy 62(2):124-142. https://doi.org/10.1086/257497

Griffin, W. A. 2006. Agent-based modeling for the theoretical biologist. Biological Theory 1(4):404-409. http://dx.doi. org/10.1162/biot.2006.1.4.404

Grimm, V., U. Berger, F. Bastiansen, S. Eliassen, V. Ginot, J. Giske, J. Goss-Custard, T. Grand, S. K. Heinz, G. Huse, A. Huth, J. U.
Jepson, C. Jørgensen, W. M. Mooij, B. Müller, G. Pe'er, C. Piou, S. F. Railsback, A. M. Robbins, M. M. Robbins, E. Rossmanith, N. Rüger, E. Strand, S. Souissi, R. A. Stillman, R. Vabø, U. Visser, and D. L. DeAngelis. 2006. A standard protocol for describing individual-based and agent-based models. Ecological Modelling 198(1-2):115-126. http://dx.doi.org/10.1016/j.ecolmodel.2006.04.023

Grimm, V., and S. F. Railsback. 2005. Individual-based modeling and ecology. Princeton University Press, Princeton, New Jersey, USA. http://dx.doi.org/10.1515/9781400850624

Grimm, V., and S. F. Railsback. 2012. Pattern-oriented modelling: a 'multi-scope' for predictive systems ecology. Philosophical Transactions of the Royal Society B: Biological Sciences 367 (1586):298-310. http://dx.doi.org/10.1098/rstb.2011.0180

Grimm, V., E. Revilla, U. Berger, F. Jeltsch, W. M. Mooij, S. F. Railsback, H.-H. Thulke, J. Weiner, T. Wiegand, and D. L. DeAngelis. 2005. Pattern-oriented modeling of agent-based complex systems: lessons from ecology. Science 310 (5750):987-991. http://dx.doi.org/10.1126/science.1116681

Gunderson, L., and S. S. Light. 2006. Adaptive management and adaptive governance in the everglades ecosystem. Policy Sciences 39(4):323-334. http://dx.doi.org/10.1007/s11077-006-9027-2

Gurung, T. R., F. Bousquet, and G. Trébuil. 2006. Companion modeling, conflict resolution, and institution building: sharing irrigation water in the Lingmuteychu Watershed, Bhutan. Ecology and Society 11(2):36. http://dx.doi.org/10.5751/ ES-01929-110236

Halbe, J., D. E. Reusser, G. Holtz, M. Haasnoot, A. Stosius, W. Avenhaus, and J. H. Kwakkel. 2015. Lessons for model use in transition research: a survey and comparison with other research areas. Environmental Innovation and Societal Transitions 15:194-210. http://dx.doi.org/10.1016/j.eist.2014.10.001

Holling, C. S. 1973. Resilience and stability of ecological systems. Annual Review of Ecology and Systematics 4:1-23. http://dx.doi. org/10.1146/annurev.es.04.110173.000245

Horan, R. D., E. P. Fenichel, K. L. S. Drury, and D. M. Lodge. 2011. Managing ecological thresholds in coupled environmentalhuman systems. Proceedings of the National Academy of Sciences 108(18):7333-7338. http://dx.doi.org/10.1073/pnas.1005431108

Huber, R., S. Briner, A. Peringer, S. Lauber, R. Seidl, A. Widmer, F. Gillet, A. Buttler, Q. B. Le, and C. Hirschi. 2013. Modeling social-ecological feedback effects in the implementation of payments for environmental services in pasture-woodlands. Ecology and Society 18(2):41. http://dx.doi.org/10.5751/ ES-05487-180241

Hughes, T. P., M. L. Barnes, D. R. Bellwood, J. E. Cinner, G. S. Cumming, J. B. C. Jackson, J. Kleypas, I. A. van de Leemput, J. M. Lough, T. H. Morrison, S. R. Palumbi, E. H. van Nes, and M. Scheffer. 2017. Coral reefs in the Anthropocene. Nature 546 (7656):82-90. http://dx.doi.org/10.1038/nature22901

Janssen, M. A. 2016. Impact of diverse behavioral theories on environmental management: explorations with Daisyworld. Pages 1690-1701 in Proceedings of the 2016 Winter Simulation Conference. IEEE, New York, New York, USA. http://dx.doi. org/10.1109/WSC.2016.7822217 
Janssen, M. A., and E. Ostrom. 2006. Empirically based, agentbased models. Ecology and Society 11(2):37. http://dx.doi. org/10.5751/ES-01861-110237

Janssen, S., and M. K. van Ittersum. 2007. Assessing farm innovations and responses to policies: a review of bio-economic farm models. Agricultural Systems 94(3):622-636. http://dx.doi. org/10.1016/j.agsy.2007.03.001

Kachergis, E. J., C. N. Knapp, M. E. Fernandez-Gimenez, J. P. Ritten, J. G. Pritchett, J. Parsons, W. Hibbs, and R. Roath. 2013. Tools for resilience management: multidisciplinary development of state-and-transition models for northwest Colorado. Ecology and Society 18(4):39. http://dx.doi.org/10.5751/ES-05805-180439

Kelly (Letcher), R. A., A. J. Jakeman, O. Barreteau, M. E. Borsuk, S. ElSawah, S. H. Hamilton, H. J. Henriksen, S. Kuikka, H. R. Maier, A. E. Rizzoli, H. van Delden, and A. A. Voinov. $2013 a$. Selecting among five common modelling approaches for integrated environmental assessment and management. Environmental Modelling \& Software 47:159-181. https://doi. org/10.1016/j.envsoft.2013.05.005

Knapp, C. N., M. Fernandez-Gimenez, E. Kachergis, and A. Rudeen. 2011. Using Participatory workshops to integrate stateand-transition models created with local knowledge and ecological data. Rangeland Ecology \& Management 64 (2):158-170. http://dx.doi.org/10.2111/REM-D-10-00047.1

Lade, S. J., L. J. Haider, G. Engström, and M. Schlüter. 2017. Resilience offers escape from trapped thinking on poverty alleviation. Science Advances 3(5):e1603043. http://dx.doi. org/10.1126/sciadv. 1603043

Lade, S. J., and S. Niiranen. 2017. Generalized modeling of empirical social-ecological systems. Natural Resource Modeling 30(3):e12129. http://dx.doi.org/10.1111/nrm.12129

Lade, S. J., S. Niiranen, J. Hentati-Sundberg, T. Blenckner, W. J. Boonstra, K. Orach, M. F. Quaas, H. Österblom, and M. Schlüter. 2015. An empirical model of the Baltic Sea reveals the importance of social dynamics for ecological regime shifts. Proceedings of the National Academy of Sciences 112(35):11120-11125. http://dx. doi.org/10.1073/pnas. 1504954112

Lade, S. J., A. Tavoni, S. A. Levin, and M. Schlüter. 2013. Regime shifts in a social-ecological system. Theoretical Ecology 6 (3):359-372. http://dx.doi.org/10.1007/s12080-013-0187-3

Levin, S., T. Xepapadeas, A.-S. Crépin, J. Norberg, A. de Zeeuw, C. Folke, T. Hughes, K. Arrow, S. Barrett, G. Daily, P. Ehrlich, N. Kautsky, K.-G. Mäler, S. Polasky, M. Troell, J. R. Vincent, and B. Walker. 2013. Social-ecological systems as complex adaptive systems: modeling and policy implications. Environment and Development Economics 18(2):111-132. http://dx.doi.org/10.1017/ $\underline{\mathrm{S} 1355770 \mathrm{X} 12000460}$

Levins, R. 1966. The strategy of model building in population biology. American Scientist 54(4):421-431. [online] URL: https:// www.jstor.org/stable/27836590

Libre, S. V. D., G. A. K. van Voorn, G. A. ten Broeke, M. Bailey, P. Berentsen, and S. R. Bush. 2015. Effects of social factors on fishing effort: the case of the Philippine tuna purse seine fishery. Fisheries Research 172:250-260. http://dx.doi.org/10.1016/j. fishres.2015.07.033
Little, L. R., A. E. Punt, B. D. Mapstone, G. A. Begg, B. Goldman, and A. J. Williams. 2009. An agent-based model for simulating trading of multi-species fisheries quota. Ecological Modelling 220 (23):3404-3412. http://dx.doi.org/10.1016/j.ecolmodel.2009.08.004

Lynam, T., W. de Jong, D. Sheil, T. Kusumanto, and K. Evans. 2007. A review of tools for incorporating community knowledge, preferences, and values into decision making in natural resources management. Ecology and Society 12(1):5. http://dx.doi. org/10.5751/ES-01987-120105

Martin, R., and M. Schlüter. 2015. Combining system dynamics and agent-based modeling to analyze social-ecological interactions - an example from modeling restoration of a shallow lake. Frontiers in Environmental Science 3:66. http://dx.doi. org/10.3389/fenvs.2015.00066

Marzloff, M. P., J. M. Dambacher, C. R. Johnson, L. R. Little, and S. D. Frusher. 2011. Exploring alternative states in ecological systems with a qualitative analysis of community feedback. Ecological Modelling 222(15):2651-2662. http://dx.doi.org/10.1016/ j.ecolmodel.2011.03.040

Matthews, R. B., N. G. Gilbert, A. Roach, J. G. Polhill, and N. M. Gotts. 2007. Agent-based land-use models: a review of applications. Landscape Ecology 22(10):1447-1459. http://dx.doi. org/10.1007/s10980-007-9135-1

Millington, J., R. Romero-Calcerrada, J. Wainwright, and G. Perry. 2008. An agent-based model of Mediterranean agricultural land-use/cover change for examining wildfire risk. Journal of Artificial Societies and Social Simulation 11(4):4. [online] URL: http://jasss.soc.surrey.ac.uk/11/4/4.html

Milner-Gulland, E. J. 2011. Integrating fisheries approaches and household utility models for improved resource management. Proceedings of the National Academy of Sciences 108 (4):1741-1746. http://dx.doi.org/10.1073/pnas.1010533108

Mollinga, P. P. 2010. Boundary work and the complexity of natural resources management. Crop Science 50(S1):S1-S9. http:// dx.doi.org/10.2135/cropsci2009.10.0570

Moore, M.-L., O. Tjornbo, E. Enfors, C. Knapp, J. Hodbod, J. A. Baggio, A. Norström, P. Olsson, and D. Biggs. 2014. Studying the complexity of change: toward an analytical framework for understanding deliberate social-ecological transformations. Ecology and Society 19(4):54. http://dx.doi.org/10.5751/ ES-06966-190454

Müller, B., F. Bohn, G. Dreßler, J. Groeneveld, C. Klassert, R. Martin, M. Schlüter, J. Schulze, H. Weise, and N. Schwarz. 2013. Describing human decisions in agent-based models - ODD + D, an extension of the ODD protocol. Environmental Modelling \& Software 48:37-48. http://dx.doi.org/10.1016/j.envsoft.2013.06.003

Müller, B., M. F. Quaas, K. Frank, and S. Baumgärtner. 2011. Pitfalls and potential of institutional change: rain-index insurance and the sustainability of rangeland management. Ecological Economics 70(11):2137-2144. http://dx.doi.org/10.1016/ j.ecolecon.2011.06.011

Nicolson, C. R., A. M. Starfield, G. P. Kofinas, and J. A. Kruse. 2002. Ten heuristics for interdisciplinary modeling projects. Ecosystems 5(4):376-384. http://dx.doi.org/10.1007/s10021-001-0081-5 
Norberg, J., and G. S. Cumming, editors. 2008. Complexity theory for a sustainable future. Columbia University Press, New York, New York, USA.

Olson, J. M., G. Alagarswamy, J. A. Andresen, D. J. Campbell, A. Y. Davis, J. Ge, M. Huebner, B. M. Lofgren, D. P. Lusch, N. J. Moore, B. C. Pijanowski, J. Qi, P. K. Thornton, N. M. Torbick, and J. Wang. 2008. Integrating diverse methods to understand climate-land interactions in East Africa. Geoforum 39 (2):898-911. http://dx.doi.org/10.1016/j.geoforum.2007.03.011

Olsson, P., C. Folke, and T. P. Hughes. 2008. Navigating the transition to ecosystem-based management of the Great Barrier Reef, Australia. Proceedings of the National Academy of Sciences 105(28):9489-9494. http://dx.doi.org/10.1073/pnas.0706905105

Olsson, P., V. Galaz, and W. J. Boonstra. 2014. Sustainability transformations: a resilience perspective. Ecology and Society 19 (4):1. http://dx.doi.org/10.5751/ES-06799-190401

Parker, D. C., S. M. Manson, M. A. Janssen, M. J. Hoffmann, and P. Deadman. 2003. Multi-agent systems for the simulation of land-use and land-cover change: a review. Annals of the Association of American Geographers 93(2):314-337. http://dx. doi.org/10.1111/1467-8306.9302004

Poile, C., and F. Safayeni. 2016. Using computational modeling for building theory: a double edged sword. Journal of Artificial Societies and Social Simulation 19(3):8. http://dx.doi. org/10.18564/jasss.3137

Polhill, J. G., T. Filatova, M. Schlüter, and A. Voinov. 2016. Modelling systemic change in coupled socio-environmental systems. Environmental Modelling \& Software 75:318-332. http:// dx.doi.org/10.1016/j.envsoft.2015.10.017

Prell, C., K. Hubacek, M. Reed, C. Quinn, N. Jin, J. Holden, T. Burt, M. Kirby, and J. Sendzimir. 2007. If you have a hammer everything looks like a nail: traditional versus participatory model building. Interdisciplinary Science Reviews 32(3):263-282. http:// dx.doi.org/10.1179/030801807X211720

Railsback, S. F., and B. C. Harvey. 2011. Importance of fish behaviour in modelling conservation problems: food limitation as an example. Journal of Fish Biology 79(6):1648-1662. http://dx. doi.org/10.1111/j.1095-8649.2011.03050.x

Reichert, P., N. Schuwirth, and S. Langhans. 2013. Constructing, evaluating and visualizing value and utility functions for decision support. Environmental Modelling \& Software 46:283-291. http:// dx.doi.org/10.1016/j.envsoft.2013.01.017

Sanchirico, J. N., and J. E. Wilen. 2001. A bioeconomic model of marine reserve creation. Journal of Environmental Economics and Management 42(3):257-276. http://dx.doi.org/10.1006/jeem.2000.1162

Sandker, M., B. M. Campbell, M. Ruiz-Pérez, J. A. Sayer, R. Cowling, H. Kassa, and A. T. Knight. 2010. The role of participatory modeling in landscape approaches to reconcile conservation and development. Ecology and Society 15(2):13. http://dx.doi.org/10.5751/ES-03400-150213

Satake, A., Y. Iwasa, and S. A. Levin. 2008. Comparison between perfect information and passive-adaptive social learning models of forest harvesting. Theoretical Ecology 1(4):189-197. http://dx. doi.org/10.1007/s12080-008-0019-z
Scheffer, M., J. Bascompte, W. A. Brock, V. Brovkin, S. R. Carpenter, V. Dakos, H. Held, E. H. van Nes, M. Rietkerk, and G. Sugihara. 2009. Early-warning signals for critical transitions. Nature 461(7260):53-59. http://dx.doi.org/10.1038/nature08227

Scheffer, M., S. Carpenter, J. A. Foley, C. Folke, and B. Walker. 2001. Catastrophic shifts in ecosystems. Nature 413 (6856):591-596. http://dx.doi.org/10.1038/35098000

Schlüter, M., J. Hinkel, P. W. G. Bots, and R. Arlinghaus. 2014. Application of the SES framework for model-based analysis of the dynamics of social-ecological systems. Ecology and Society 19(1):36. http://dx.doi.org/10.5751/ES-05782-190136

Schlüter, M., R. R. J. Mcallister, R. Arlinghaus, N. Bunnefeld, K. Eisenack, F. Hölker, E. J. Milner-Gulland, B. Müller, E. Nicholson, M. Quaas, and M. Stöven. 2012. New horizons for managing the environment: a review of coupled social-ecological systems modeling. Natural Resource Modeling 25(1):219-272. http://dx.doi.org/10.1111/j.1939-7445.2011.00108.x

Schouten, M., P. Opdam, N. Polman, and E. Westerhof. 2013. Resilience-based governance in rural landscapes: experiments with agri-environment schemes using a spatially explicit agentbased model. Land Use Policy 30(1):934-943. http://dx.doi. org/10.1016/j.landusepol.2012.06.008

Schulze, J., B. Müller, J. Groeneveld, and V. Grimm. 2017. Agentbased modelling of social-ecological systems: achievements, challenges, and a way forward. Journal of Artificial Societies and Social Simulation 20(2):8. http://dx.doi.org/10.18564/jasss.3423

Seidl, R. 2015. A functional-dynamic reflection on participatory processes in modeling projects. Ambio 44(8):750-765. http://dx. doi.org/10.1007/s13280-015-0670-8

Seppelt, R., F. Müller, B. Schröder, and M. Volk. 2009. Challenges of simulating complex environmental systems at the landscape scale: a controversial dialogue between two cups of espresso. Ecological Modelling 220(24):3481-3489. http://dx.doi.org/10.1016/ j.ecolmodel.2009.09.009

Smajgl, A. 2010. Challenging beliefs through multi-level participatory modelling in Indonesia. Environmental Modelling \& Software 25(11):1470-1476. http://dx.doi.org/10.1016/j. envsoft.2010.04.008

Smajgl, A., and O. Barreteau, editors. 2014. Empirical agent-based modelling - challenges and solutions: Volume 1, the characterisation and parameterisation of empirical agent-based models. Springer New York, New York, USA. http://dx.doi.org/10.1007/978-1-4614-6134-0

Smajgl, A., and E. Bohensky. 2013. Behaviour and space in agentbased modelling: poverty patterns in East Kalimantan, Indonesia. Environmental Modelling \& Software 45:8-14. http:// dx.doi.org/10.1016/j.envsoft.2011.10.014

Smajgl, A., and J. Ward. 2015. Evaluating participatory research: framework, methods and implementation results. Journal of Environmental Management 157:311-319. http://dx.doi.org/10.1016/ j.jenvman.2015.04.014

Smith, M. D., and J. E. Wilen. 2003. Economic impacts of marine reserves: the importance of spatial behavior. Journal of Environmental Economics and Management 46(2):183-206. http:// dx.doi.org/10.1016/S0095-0696(03)00024-X 
Spies, T. A., E. White, A. Ager, J. D. Kline, J. P. Bolte, E. K. Platt, K. A. Olsen, R. J. Pabst, A. M. G. Barros, J. D. Bailey, S. Charnley, A. T. Morzillo, J. Koch, M. M. Steen-Adams, P. H. Singleton, J. Sulzman, C. Schwartz, and B. Csuti. 2017. Using an agent-based model to examine forest management outcomes in a fire-prone landscape in Oregon, USA. Ecology and Society 22(1):25. http:// dx.doi.org/10.5751/ES-08841-220125

Stefanska, J., P. Magnuszewski, J. Sendzimir, P. Romaniuk, T. Taillieu, A. Dubel, Z. Flachner, and P. Balogh. 2011. A gaming exercise to explore problem-solving versus relational activities for river floodplain management. Environmental Policy and Governance 21(6):454-471. http://dx.doi.org/10.1002/eet.586

Sterman, J. D. 2001. System dynamics modeling: tools for learning in a complex world. California Management Review 43(4):8-25. https://doi.org/10.2307/41166098

Tavoni, A., M. Schlüter, and S. Levin. 2012. The survival of the conformist: social pressure and renewable resource management. Journal of Theoretical Biology 299:152-161. http://dx.doi. org/10.1016/j.jtbi.2011.07.003

Tengö, M., E. S. Brondizio, T. Elmqvist, P. Malmer, and M. Spierenburg. 2014. Connecting diverse knowledge systems for enhanced ecosystem governance: the multiple evidence base approach. Ambio 43(5):579-591. http://dx.doi.org/10.1007/ s13280-014-0501-3

Thulke, H.-H., M. Lange, J. A. Tratalos, T. A. Clegg, G. McGrath, L. O'Grady, P. O'Sullivan, M. L. Doherty, D. A. Graham, and S. J. More. 2018. Eradicating BVD, reviewing Irish programme data and model predictions to support prospective decision making. Preventive Veterinary Medicine 150:151-161. http://dx.doi. org/10.1016/j.prevetmed.2017.11.017

Turner, M. G. 2003. Modeling for synthesis and integration: forests, people, and riparian coarse woody debris. Pages 83-110 in C. D. Canham, J. J. Cole, and W. K. Lauenroth, editors. Models in ecosystem science. Princeton University Press, Princeton, New Jersey, USA.

van Daalen, C. E., L. Dresen, and M. A. Janssen. 2002. The roles of computer models in the environmental policy life cycle. Environmental Science \& Policy 5(3):221-231. http://dx.doi. org/10.1016/S1462-9011(02)00040-0

van den Belt, M. 2004. Mediated modeling: a system dynamics approach to environmental consensus building. Island Press, Washington, D.C., USA.

van Poorten, B. T., R. Arlinghaus, K. Daedlow, and S. S. HaertelBorer. 2011. Social-ecological interactions, management panaceas, and the future of wild fish populations. Proceedings of the National Academy of Sciences 108(30):12554-12559. http://dx. doi.org/10.1073/pnas.1013919108

van Putten, I. E., S. Kulmala, O. Thébaud, N. Dowling, K. G. Hamon, T. Hutton, and S. Pascoe. 2012. Theories and behavioural drivers underlying fleet dynamics models. Fish and Fisheries 13 (2):216-235. http://dx.doi.org/10.1111/j.1467-2979.2011.00430.x

Voinov, A., and E. J. B. Gaddis. 2008. Lessons for successful participatory watershed modeling: a perspective from modeling practitioners. Ecological Modelling 216(2):197-207. http://dx.doi. org/10.1016/j.ecolmodel.2008.03.010

Voinov, A., N. Kolagani, M. K. McCall, P. D. Glynn, M. E. Kragt, F. O. Ostermann, S. A. Pierce, and P. Ramu. 2016. Modelling with stakeholders - next generation. Environmental Modelling \& Software 77:196-220. http://dx.doi.org/10.1016/j.envsoft.2015.11.016

Walsh, S. J., and C. F. Mena. 2016. Interactions of social, terrestrial, and marine sub-systems in the Galapagos Islands, Ecuador. Proceedings of the National Academy of Sciences 113 (51):14536-14543. http://dx.doi.org/10.1073/pnas.1604990113

Westley, F. R., O. Tjornbo, L. Schultz, P. Olsson, C. Folke, B. Crona, and Ö. Bodin. 2013. A theory of transformative agency in linked social-ecological systems. Ecology and Society 18(3):27. http://dx.doi.org/10.5751/ES-05072-180327

Westoby, M., B. H. Walker, and I. Noy-Meir. 1989. Opportunistic management for rangelands not at equilibrium. Journal of Range Management 42(4):266-274.

Wiedermann, M., J. F. Donges, J. Heitzig, W. Lucht, and J. Kurths. 2015. Macroscopic description of complex adaptive networks coevolving with dynamic node states. Physical Review E 91 (5):052801. http://dx.doi.org/10.1103/PhysRevE.91.052801

Wiegand, T., F. Jeltsch, I. Hanski, and V. Grimm. 2003. Using pattern-oriented modeling for revealing hidden information: a key for reconciling ecological theory and application. Oikos 100 (2):209-222. http://dx.doi.org/10.1034/j.1600-0706.2003.12027.x

Zagaria, C., C. J. E. Schulp, T. Kizos, D. Gounaridis, and P. H. Verburg. 2017. Cultural landscapes and behavioral transformations: an agent-based model for the simulation and discussion of alternative landscape futures in East Lesvos, Greece. Land Use Policy 65:26-44. http://dx.doi.org/10.1016/j.landusepol.2017.03.022

Zimmermann, A., T. Heckelei, and I. P. Domínguez. 2009. Modelling farm structural change for integrated ex-ante assessment: review of methods and determinants. Environmental Science \& Policy 12(5):601-618. http://dx.doi.org/10.1016/j. envsci.2009.01.014 
Appendix for "The potential of models and modelling for social-ecological systems research - the reference frame MODSES"

\section{Section 1: Selection of papers for review of resilience models (from 1998-2011)}

We used the "Web of Science" database to identify relevant papers for our review. We searched for process-based modeling studies that dealt with resource management issues of social-ecological systems and were interested in resilience questions. We are aware that modeling studies that do not explicitly mention the term "resilience" but look at for instance "stability", "persistence" etc. may also contribute to resilience research. However in order to have a manageable number of papers we restricted the search to the term "resilience".

The exact query used was: "TS=(resilience AND model AND ecol* AND (management OR resource OR governance))". The search was carried out in April 2009 and repeated for papers from 2009 to 2011 in April 2012. 289 papers were detected by the search algorithm.

After reading the abstracts/the whole papers we eliminated those studies that did not fulfilled our criteria. For instance we did not want to investigate pure conceptual models which present only a system description or model framework without any model solution. Since we were interested in dynamic process-based models we excluded furthermore pure statistical models. Some of the studies presented a purely ecological model without any management or use - a further criterion for exclusion. Finally only 52 papers out of the 289 papers were left over for review (see below for a list of the papers). The years in which articles were published are depicted in Figure A1.

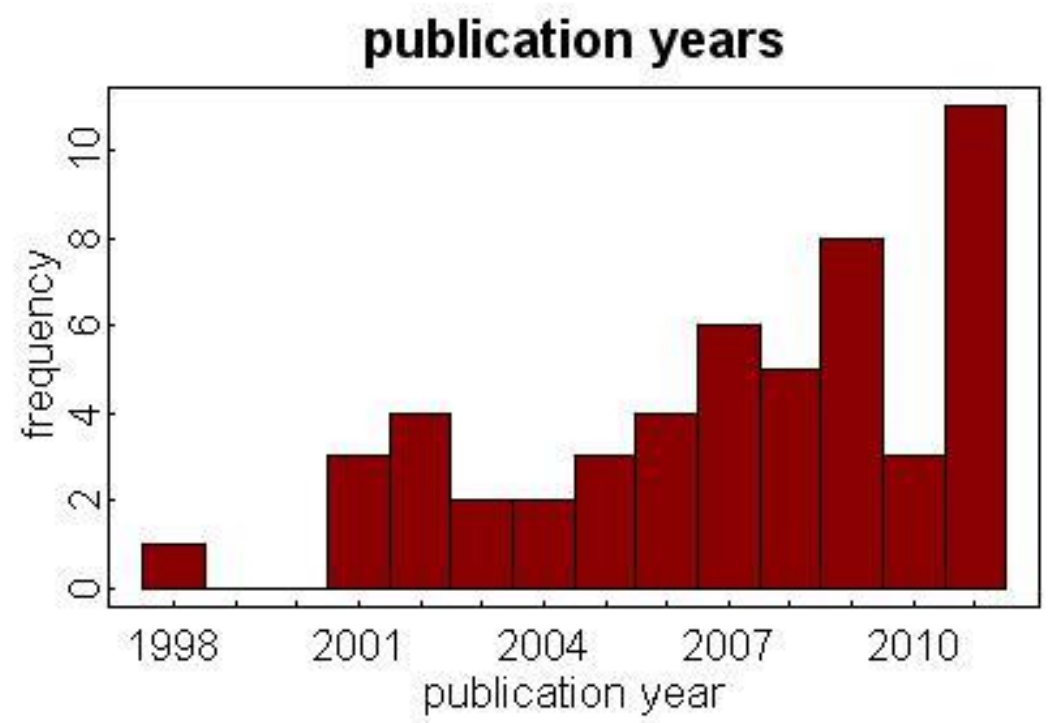

Figure A1: Years of publication

Papers included in review (from 1998-2011) 
Albers, H. J.; Goldbach, M. J. \& Kaffine, D. T. (2006), 'Implications of agricultural policy for species invasion in shifting cultivation systems', ENVIRONMENT AND DEVELOPMENT ECONOMICS 11(4), 429-452.

Anderies, J.; Janssen, M. \& Walker, B. (2002), 'Grazing management, resilience, and the dynamics of a fire-driven rangeland system', ECOSYSTEMS 5(1), 23-44.

Anderies, J. M.; Ryan, P. \& Walker, B. H. (2006), 'Loss of resilience, crisis, and institutional change: Lessons from an intensive agricultural system in southeastern Australia', ECOSYSTEMS 9(6), 865878.

Anderies, John M., and Michelle Hegmon. 2011. "Robustness and Resilience Across Scales: Migration and Resource Degradation in the Prehistoric US Southwest." Ecology and Society 16 (2).

Baskett, Marissa L., Roger M. Nisbet, Carrie V. Kappel, Peter J. Mumby, and Steven D. Gaines. 2010. "Conservation Management Approaches to Protecting the Capacity for Corals to Respond to Climate Change: a Theoretical Comparison." Global Change Biology 16 (4): 1229-1246.

Batabyal, A. (2002), 'Human actions, the survival of keystone species, and the resilience of ecologicaleconomic systems', RESOURCES POLICY 28(3-4), 153-157.

Batabyal, A. (2001), 'A theoretical inquiry into aspects of the structure and the management of ecological-economic systems', STOCHASTIC ENVIRONMENTAL RESEARCH AND RISK ASSESSMENT 15(2), 173-184.

Baumgaertner, Stefan, Sandra Derissen, Martin F. Quaas, and Sebastian Strunz. 2011. "Consumer Preferences Determine Resilience of Ecological-Economic Systems." Ecology and Society 16 (4).

Blackwood, Julie C., and Alan Hastings. 2011. "The Effect of Time Delays on Caribbean Coral-algal Interactions." Journal of Theoretical Biology 273 (1) :37-43.

Bodin, O. \& Norberg, J. (2005), 'Information network topologies for enhanced local adaptive management', ENVIRONMENTAL MANAGEMENT 35(2), 175-193.

Bolte, J. P.; Hulse, D. W.; Gregory, S. V. \& Smith, C. (2007), 'Modeling biocomplexity - actors, landscapes and alternative futures', ENVIRONMENTAL MODELLING \& SOFTWARE 22(5 Sp. Iss. SI), 570-579.

Bueno, Newton, and Xavier Basurto. 2009. "Resilience and Collapse of Artisanal Fisheries: a System Dynamics Analysis of a Shellfish Fishery in the Gulf of California, Mexico." Sustainability Science 4 (2): 139-149. doi:10.1007/s11625-009-0087-z.

Carpenter, S. \& Brock, W. (2004), 'Spatial complexity, resilience, and policy diversity: Fishing on lakerich landscapes', ECOLOGY AND SOCIETY 9(1).

Carpenter, S. R. \& Brock, W. A. (2008), 'Adaptive Capacity and Traps', ECOLOGY AND SOCIETY 13(2). 
Chapin, F.; Rupp, T.; Starfield, A.; DeWilde, L.; Zavaleta, E.; Fresco, N.; Henkelman, J. \& McGuire, A. (2003), 'Planning for resilience: modeling change in human-fire interactions in the Alaskan boreal forest', FRONTIERS IN ECOLOGY AND THE ENVIRONMENT 1(5), 255-261.

Chisholm, R. A. \& Filotas, E. (2009), 'Critical slowing down as an indicator of transitions in two-species models', Journal Of Theoretical Biology 257(1), 142--149.

Cordonnier, T.; Courbaud, B.; Berger, F. \& Franc, A. (2008), 'Permanence of resilience and protection efficiency in mountain Norway spruce forest stands: A simulation study', FOREST ECOLOGY AND MANAGEMENT 256(3), 347-354.

Dakos, Vasilis, Sonia Kefi, Max Rietkerk, Egbert H. van Nes, and Marten Scheffer. 2011. "Slowing Down in Spatially Patterned Ecosystems at the Brink of Collapse." American Naturalist 177 (6): E153-E166. doi:10.1086/659945.

D'Alessandro, S. (2007), 'Non-linear dynamics of population and natural resources: The emergence of different patterns of development', ECOLOGICAL ECONOMICS 62(3-4), 473-481.

Derissen, Sandra, Martin F. Quaas, and Stefan Baumgaertner. 2011. "The Relationship Between Resilience and Sustainability of Ecological-economic Systems." Ecological Economics 70 (6) (April 15): 1121-1128. doi:10.1016/j.ecolecon.2011.01.003.

Dougill, Andrew J., Evan D. G. Fraser, and Mark S. Reed. 2010. "Anticipating Vulnerability to Climate Change in Dryland Pastoral Systems: Using Dynamic Systems Models for the Kalahari." Ecology and Society 15 (2).

Figueiredo, Joana, and Henrique M. Pereira. 2011. "Regime Shifts in a Socio-ecological Model of Farmland Abandonment." Landscape Ecology 26 (5: 737-749. doi:10.1007/s10980-011-9605-3.

Fletcher, C. S. \& Hilbert, D. W. (2007), 'Resilience in landscape exploitation systems', ECOLOGICAL MODELLING 201(3-4), 440-452.

Forbis, T. A.; Provencher, L.; Frid, L. \& Medlyn, G. (2006), 'Great Basin Land Management planning using ecological modeling', ENVIRONMENTAL MANAGEMENT 38(1), 62-83.

Gobattoni, Federica, Raffaele Pelorosso, Giuliana Lauro, Antonio Leone, and Roberto Monaco. 2011. "A Procedure for Mathematical Analysis of Landscape Evolution and Equilibrium Scenarios Assessment." Landscape and Urban Planning 103 (3-4): 289-302. doi:10.1016/j.landurbplan.2011.08.011.

Grafton, R.; Kompas, T. \& Lindenmayer, D. (2005), 'Marine reserves with ecological uncertainty', BULLETIN OF MATHEMATICAL BIOLOGY 67(5), 957-971.

Grune, L.; Kato, M. \& Semmler, W. (2005), 'Solving ecological management problems using dynamic programming', JOURNAL OF ECONOMIC BEHAVIOR \& ORGANIZATION 57(4), 448-473. 
Guttal, V. \& Jayaprakash, C. (2007), 'Impact of noise on bistable ecological systems', ECOLOGICAL MODELLING 201(3-4), 420-428.

Guttal, Vishwesha, and C. Jayaprakash. 2008. "Spatial Variance and Spatial Skewness: Leading Indicators of Regime Shifts in Spatial Ecological Systems." Theoretical Ecology 2 (1) (December 2): 3-12. doi:10.1007/s12080-008-0033-1.

Gutierrez, A. P, G. Gilioli, and J. Baumgärtner. 2009. "Ecosocial Consequences and Policy Implications of Disease Management in East African Agropastoral Systems." Proceedings of the National Academy of Sciences 106 (31): 13136-13141.

Horan, Richard D., Eli P. Fenichel, Kevin L. S. Drury, and David M. Lodge. 2011. "Managing Ecological Thresholds in Coupled Environmental-human Systems." Proceedings of the National Academy of Sciences of the United States of America 108 (18: 7333-7338. doi:10.1073/pnas.1005431108.

Leroux, A. D. \& Creedy, J. (2007), 'Optimal land conversion and growth with uncertain biodiversity costs', ECOLOGICAL ECONOMICS 61(2-3), 542-549.

Leslie, Heather M., Maja Schlüter, Richard Cudney-Bueno, and Simon A. Levin. 2009. "Modeling Responses of Coupled Social-ecological Systems of the Gulf of California to Anthropogenic and Natural Perturbations." Ecological Research 24 (3) (April 24): 505-519. doi:10.1007/s11284-0090603-8.

Li, Hongjun, Zhijun Liu, Li Zheng, and Yuping Lei. 2011. "Resilience Analysis for Agricultural Systems of North China Plain Based on a Dynamic System Model." Scientia Agricola 68 (1): 8-17.

Loudermilk, E. L., W. P. Cropper, Jr., R. J. Mitchell, and H. Lee. 2011. “Longleaf Pine (Pinus Palustris) and Hardwood Dynamics in a Fire-maintained Ecosystem: A Simulation Approach." Ecological Modelling 222 (15): 2733-2750. doi:10.1016/j.ecolmodel.2011.05.004.

Ludwig, D.; Carpenter, S. \& Brock, W. (2003), 'Optimal phosphorus loading for a potentially eutrophic lake', ECOLOGICAL APPLICATIONS 13(4), 1135-1152.

Ludwig, J.; Coughenour, M.; Liedloff, A. \& Dyer, R. (2001), 'Modelling the resilience of Australian savanna systems to grazing impacts', ENVIRONMENT INTERNATIONAL 27(2-3 Sp. Iss. SI), 167-172.

Martin, S. (2004), 'The cost of restoration as a way of defining resilience: a viability approach applied to a model of lake eutrophication', ECOLOGY AND SOCIETY 9(2).

Ortiz, M. \& Wolff, M. (2002), 'Dynamical simulation of mass-balance trophic models for benthic communities of north-central Chile: assessment of resilience time under alternative management scenarios', ECOLOGICAL MODELLING 148(3), 277-291.

Pawlowski, C. W, and C. McCord. 2009. "A Markov Model for Assessing Ecological Stability Properties." Ecological Modelling 220 (2): 86-95. 
Perez-Espana, H. \& Arreguin-Sanchez, F. (2001), 'An inverse relationship between stability and maturity in models of aquatic ecosystems', ECOLOGICAL MODELLING 145(2-3), 189-196.

Peterson, G. (2002), 'Estimating resilience across landscapes', CONSERVATION ECOLOGY 6(1).

Popp, A., S. Domptail, N. Blaum, and F. Jeltsch. 2009. "Landuse Experience Does Qualify for Adaptation to Climate Change." Ecological Modelling 220 (5): 694-702.

Ranjan, R.; Marshall, E. \& Shortle, J. (2008), 'Optimal renewable resource management in the presence of endogenous risk of invasion', Journal Of Environmental Management 89(4), 273-283.

Samhouri, J. F, P. S Levin, and C. H Ainsworth. 2010. "Identifying Thresholds for Ecosystem-based Management." PLoS One 5 (1): e8907.

Satake, Akiko, Yoh Iwasa, and Simon A. Levin. 2008. "Comparison Between Perfect Information and Passive-adaptive Social Learning Models of Forest Harvesting." Theoretical Ecology 1 (4): 189197. doi:10.1007/s12080-008-0019-z.

Schlüter, M. \& Pahl-Wostl, C. (2007), 'Mechanisms of resilience in common-pool resource management systems: an agent-based model of water use in a river basin', ECOLOGY AND SOCIETY 12(2).

Schlüter, Maja, Heather Leslie, and Simon Levin. 2009. "Managing Water-use Trade-offs in a Semiarid River Delta to Sustain Multiple Ecosystem Services: a Modeling Approach." Ecological Research 24 (3) : 491-503. doi:10.1007/s11284-008-0576-z.

Sengupta, N. (2006), 'Fragmented landholding, productivity, and resilience management', ENVIRONMENT AND DEVELOPMENT ECONOMICS 11(4), 507-532.

Serrat-Capdevila, A., A. Browning-Aiken, K. Lansey, T. Finan, J. Valdés, and others. 2009. "Increasing Social-ecological Resilience by Placing Science at the Decision Table: The Role of the San Pedro Basin (Arizona) Decision-support System Model." Ecology and Society 14 (1): 37.

Thorsen, B. \& Helles, F. (1998), 'Optimal stand management with endogenous risk of sudden destruction', FOREST ECOLOGY AND MANAGEMENT 108(3), 287-299.

van Apeldoorn, Dirk F., Kasper Kok, Marthijn P. W. Sonneveld, and Tom (A) Veldkamp. 2011. "Panarchy Rules: Rethinking Resilience of Agroecosystems, Evidence from Dutch Dairy-Farming." Ecology and Society 16 (1). 


\section{Criteria describing field of application and model purpose}

A Type of Ecosystem
1. rangeland
2. forest
3. coral reef
4. fisheries
5. lake eutrophication
6. agriculture
7. land management (general)
8. water management (general)
9. not specified

B Type of Social System

1. Single manager

2. Several managers not interacting with each other

3. Social manager

4. Network of actors

5. Actors not specified

C Model purpose

1. system understanding

2. forecasting or prediction (in quantitative manner)

3. management or decision support (in specific context, with management recommendations)

4. communication (to management)

5. learning (model used to change mental models)

Criteria describing model formulation, complexity and model solution

\section{E Type of model}

1. difference and differential equation model

2. rule-based model

3. state and transition model

F Model complexity

1. general model/conceptual model

2. site/context-specific

G Number of model parameters

1. $\operatorname{low}(<5)$ 
2. medium $(5<p<15)$

3. high $(>15)$

M Dynamics

1. deterministic

2. stochastic

Criteria describing space and time

I Spatial Scale

1. local

2. regional

3. global

J Time

1. not dynamic

2. dynamic with continuous time

3. dynamic with discrete time

O Type of disturbance and change

1. variability in environmental variables

2. shocks in environmental variables (e.g. droughts)

3. changes in anthropogenic variables, e.g. management

Note: More in the sense of abrupt shocks

P Feedbacks between social and ecological system

1. no

2. yes

\section{Criteria which represent the link to real world and the level of integration}

R Uncertainty

1. not considered

2. considered

T Model validation

1. no

2. yes 
U Sensitivity analysis

1. no

2. yes

Z Model limits

1. discussed

2. not discussed

AA Link to "real world"

1. parameterized with empirical data

2. validated with empirical data / pattern

3. application for management discussed

4. no link

\section{Criteria related to resilience theory}

$\checkmark$ Resilience concept

1. resilience $=$ return time to equilibrium ("technical resilience")

2. resilience $=$ capacity of system to maintain structure and function when disturbed

3. other use of resilience term

4. not specified

W Resilience Mechanism

1. buffer in system structure

2. response diversity

3. functional diversity

4. heterogeneity

5. time lags

6. cross scale effect

7. adaptive capacity of management

8. others

9. not specified

$\mathrm{X}$ Measures of resilience

1. return time to equilibrium

2. size of basin of attraction

3. position of system in relation to threshold

4. performance indicators (productivity)

5. others

6. not specified 
Y Additional considered aspects of resilience

1. adaptive cycle

2. panarchy (cross scale interactions)

3. adaptability

4. transformability

5. slow and fast variables

6. memory effect

7. thresholds

\section{Section 3: Historical use of modeling in resilience research}

Table A1: Results of the review of 52 models of resilience from 1998-2011

\begin{tabular}{|c|c|c|c|}
\hline Study aims & Purpose of the model & $\begin{array}{l}\text { \# of } \\
\text { papers }\end{array}$ & Key insights \\
\hline \multirow{5}{*}{$\begin{array}{l}\text { Understanding } \\
\text { SES persistence }\end{array}$} & $\begin{array}{l}\text { System understanding } \\
\text { Assessment of resilience of a specific } \\
\text { system }\end{array}$ & 6 & \multirow{5}{*}{$\begin{array}{l}\text { Few models include feedbacks } \\
\text { between social and ecological } \\
\text { system } \\
\text { Social system often not } \\
\text { specified (e.g. only } \\
\text { represented as variable that } \\
\text { drives the ecological system) }\end{array}$} \\
\hline & $\begin{array}{l}\text { Identification of system characteristics and } \\
\text { mechanisms that determine persistence } \\
\text { - buffer } \\
\text { - response diversity }\end{array}$ & 11 & \\
\hline & $\begin{array}{l}\text { - governance or network structure } \\
\text { - connectivity }\end{array}$ & & \\
\hline & $\begin{array}{l}\text { Development of methods to operationalize } \\
\text { and analyze resilience; predict critical } \\
\text { transitions }\end{array}$ & 6 & \\
\hline & $\begin{array}{l}\text { Development of measures to quantify } \\
\text { resilience or indicators of critical } \\
\text { transitions }\end{array}$ & 5 & \\
\hline \multirow{5}{*}{$\begin{array}{l}\text { Managing SES } \\
\text { persistence }\end{array}$} & Decision/Management support & & \multirow{5}{*}{$\begin{array}{l}\text { Lack of explicit links with real } \\
\text { world (validation, uncertainty } \\
\text { analysis, sensitivity analysis) } \\
\text { Only few studies look at robus } \\
\text { strategies }\end{array}$} \\
\hline & - Explorative assessment of alternative & 10 & \\
\hline & $\begin{array}{l}\text { management measures } \\
\text { - Assessing the tradeoff between }\end{array}$ & 10 & \\
\hline & resilience and economic productivity & 3 & \\
\hline & $\begin{array}{l}\text { Development of optimal management } \\
\text { strategies }\end{array}$ & 7 & \\
\hline $\begin{array}{l}\text { Understanding } \\
\text { and managing } \\
\text { adaptation and } \\
\text { transformation }\end{array}$ & $\begin{array}{l}\text { Model purpose: System understanding } \\
\text { Understanding adaptive capacity and } \\
\text { traps }\end{array}$ & 4 & $\begin{array}{l}\text { Only few studies address } \\
\text { adaptation of social system to } \\
\text { change } \\
\text { No study addresses } \\
\text { transformation }\end{array}$ \\
\hline
\end{tabular}

\section{Detailed results of the review}


Social-ecological systems considered and integration of the ecological and social subsystems
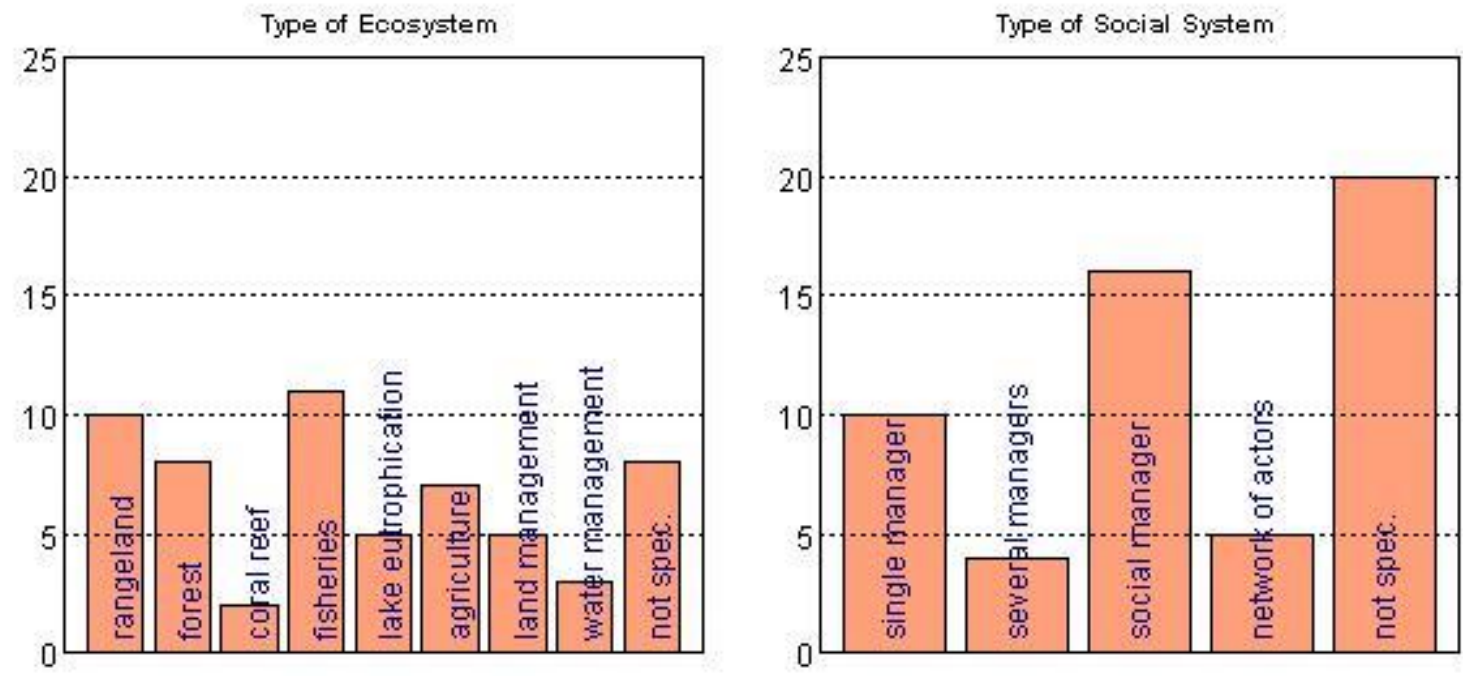

Figure A2: Ecological system/resource system (a) and social systems (b) regarded (Scale: number of papers out of all papers included in review (52))

The investigation shows that modeling studies about resilience have been developed for all different types of ecosystems or resource systems (rangeland, forest, coral reefs, fisheries, lakes, agriculture, land management and water management) (cf. Figure A2a). However, the social system is often not further specified (cf. Figure A2b), but rather represented as a change in a driving variable that is implicitly caused by change in management. Apart from that $31 \%$ of the studies assume a social manager and $19 \%$ a single one. Only in few cases a network of actors is considered (e.g. Bodin and Norberg (2005)).

The majority of studies (57\%) consider feedbacks between social and ecological systems. However it is revealed that the inclusion of feedbacks varies for different model types: Social-ecological feedbacks are more present in the generic models (62\%) compared to context-specific models (50\%). Furthermore social-ecological feedbacks are more often included in models that apply differential or difference equations (64.0\%) compared to rule-based (40\%) and state and transition models (45\%) (no figure).

Investigating whether disturbance is caused by anthropogenic or ecological variables the following results were depicted. In $25 \%$ of the papers disturbance was caused by variability in environmental variables, $35 \%$ caused by shocks in environmental variables and $69 \%$ caused by changes in anthropogenic variables (cf. Figure A3). 


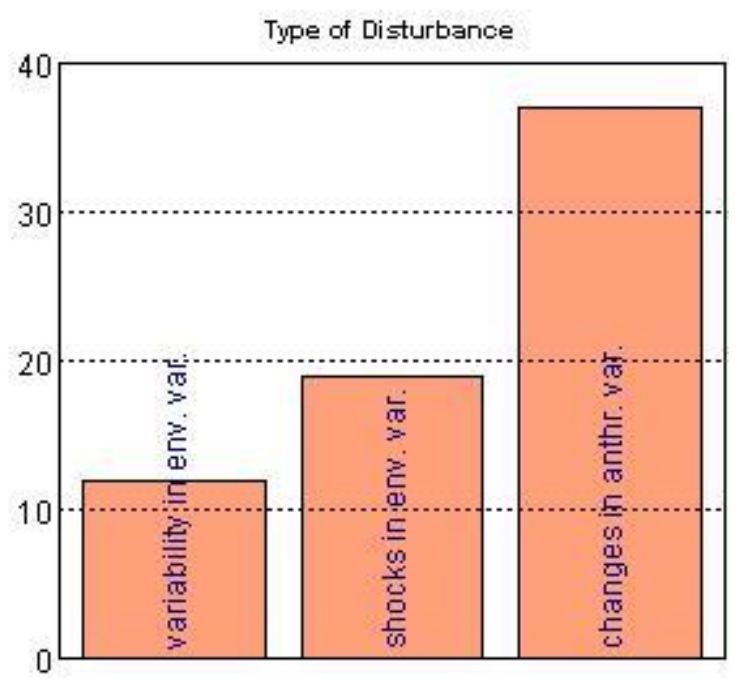

Figure A3: Types of disturbances represented in the models (Scale: number of papers out of all papers included in review (52))

\section{Modelling techniques and system representation}

Regarding the model type, the review process revealed that the majority $(75 \%)$ of the studies used difference and differential equation to formulate the model, $19 \%$ used rule based models and $21 \%$ state and transition models (multiple answers possible, e.g. Bodin 2005 used differential equation to describe the ecological model and multi-agent simulation for the social system).

$46 \%$ of the studies are stochastic. All models are formulated in a dynamic manner: $58 \%$ with continuous time, $42 \%$ with discrete time. From the spatial scale point of view: $67 \%$ addressed a local problem and $31 \%$ a regional. Two studies addressed a global scale.

Another focus of our review was set on whether the model built is context specific or is rather of general character (generic). The majority of the model studies used a generic model (67\%). $35 \%$ of the models where context-specific (double entries were possible.) In a first specification, we wanted to investigate, whether a context-specific study uses another model description (rule-based vs. purely analytical) than a general one. Our review showed the following: Most general models were described by difference or differential equations (77\%), secondly $18 \%$ by state-and transition models and $5 \%$ by rule-based models. Context-specific models are priorly formulated by rule-based models (38\%) and $43 \%$ by equation-based approaches and $19 \%$ by state-and-transition models.

In a second specification, we wanted to investigate, if the utilization of context-specific vs. general model approach depends on the model purpose. We revealed the following: Models that address management issues, aim at forecast or support communication are rather context-specific than general and beside from that more complex (via number of parameters) compared to models with purpose understanding (Figures A4b, c). Consequently more than $50 \%$ of the management support models have high number of parameters, while most of the system understandings models have 
medium numbers. There are only very few models with a low number of parameters (in system understanding) (Fig. A4c).

A further difference in system representation depended on the modeled resource system: In rangeland, forest, fisheries, agriculture, land and water management there are both general and context-specific models. However for lake eutrophication, coral reef and studies where the type of ecosystem is not specified exclusively general models were used. Apart from coral reef, different all model types appear for the resource systems. State and transition models are not as common, mainly used in models about rangelands, forests and in models where the resource system is not specified.
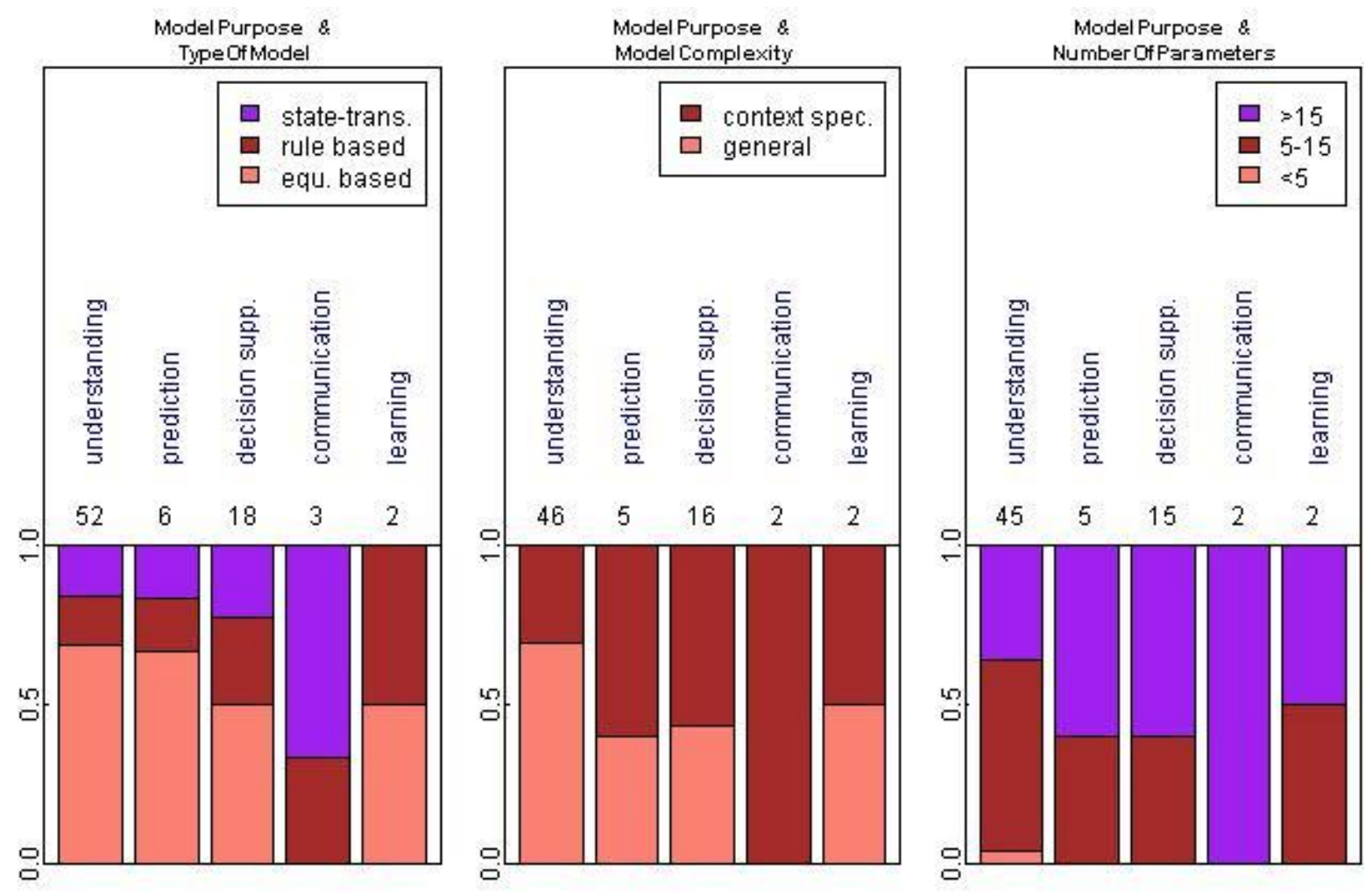

Figure A4: Relationship between model purpose and modeling technique (a) model type, b) model complexity and c) number of parameters used). 